\title{
Contribution of oil and natural gas production to renewed increase in atmospheric methane (2007-2014): top-down estimate from ethane and methane column observations
}

\author{
Petra Hausmann ${ }^{1}$, Ralf Sussmann ${ }^{1}$, and Dan Smale ${ }^{2}$ \\ ${ }^{1}$ Karlsruhe Institute of Technology, IMK-IFU, Garmisch-Partenkirchen, Germany \\ ${ }^{2}$ National Institute of Water and Atmospheric Research, Lauder, New Zealand \\ Correspondence to: Petra Hausmann (petra.hausmann@kit.edu)
}

Received: 30 November 2015 - Published in Atmos. Chem. Phys. Discuss.: 21 December 2015

Revised: 18 February 2016 - Accepted: 5 March 2016 - Published: 11 March 2016

\begin{abstract}
Harmonized time series of column-averaged mole fractions of atmospheric methane and ethane over the period 1999-2014 are derived from solar Fourier transform infrared (FTIR) measurements at the Zugspitze summit $\left(47^{\circ} \mathrm{N}, 11^{\circ} \mathrm{E} ; 2964 \mathrm{~m}\right.$ a.s.l. $)$ and at Lauder $\left(45^{\circ} \mathrm{S}, 170^{\circ} \mathrm{E}\right.$; $370 \mathrm{~m}$ a.s.l.). Long-term trend analysis reveals a consistent renewed methane increase since 2007 of 6.2 [5.6, 6.9] $\mathrm{ppb} \mathrm{yr}^{-1}$ (parts-per-billion per year) at the Zugspitze and $6.0[5.3,6.7] \mathrm{ppb} \mathrm{yr}^{-1}$ at Lauder $(95 \%$ confidence intervals). Several recent studies provide pieces of evidence that the renewed methane increase is most likely driven by two main factors: (i) increased methane emissions from tropical wetlands, followed by (ii) increased thermogenic methane emissions due to growing oil and natural gas production. Here, we quantify the magnitude of the second class of sources, using long-term measurements of atmospheric ethane as a tracer for thermogenic methane emissions. In 2007, after years of weak decline, the Zugspitze ethane time series shows the sudden onset of a significant positive trend $\left(2.3[1.8,2.8] \times 10^{-2} \mathrm{ppb} \mathrm{yr}^{-1}\right.$ for 2007-2014), while a negative trend persists at Lauder after $2007(-0.4[-0.6$, $\left.-0.1] \times 10^{-2} \mathrm{ppb} \mathrm{yr}^{-1}\right)$. Zugspitze methane and ethane time series are significantly correlated for the period 2007-2014 and can be assigned to thermogenic methane emissions with an ethane-to-methane ratio (EMR) of 12-19\%. We present optimized emission scenarios for 2007-2014 derived from an atmospheric two-box model. From our trend observations we infer a total ethane emission increase over the period 20072014 from oil and natural gas sources of $1-11 \mathrm{Tg} \mathrm{yr}^{-1}$ along with an overall methane emission increase of $24-45 \mathrm{Tg} \mathrm{yr}^{-1}$. Based on these results, the oil and natural gas emission con-
\end{abstract}

tribution $(C)$ to the renewed methane increase is deduced using three different emission scenarios with dedicated EMR ranges. Reference scenario 1 assumes an oil and gas emission combination with $\mathrm{EMR}=7.0-16.2 \%$, which results in a minimum contribution $C>39 \%$ (given as lower bound of $95 \%$ confidence interval). Beside this most plausible scenario 1 , we consider two less realistic limiting cases of pure oil-related emissions (scenario 2 with EMR $=16.2-31.4 \%$ ) and pure natural gas sources (scenario 3 with $\mathrm{EMR}=4.4$ $7.0 \%$ ), which result in $C>18 \%$ and $C>73 \%$, respectively. Our results suggest that long-term observations of columnaveraged ethane provide a valuable constraint on the source attribution of methane emission changes and provide basic knowledge for developing effective climate change mitigation strategies.

\section{Introduction}

Methane $\left(\mathrm{CH}_{4}\right)$ is the second most important anthropogenic greenhouse gas and responsible for about $20 \%$ of global warming since preindustrial times (Kirschke et al., 2013). Due to its relatively short atmospheric lifetime of about 9 years, methane is an attractive target for climate change mitigation strategies in the next few decades (Dlugokencky et al., 2011). These require an accurate understanding of the global and regional atmospheric methane budget, which is determined by a large variety of natural and anthropogenic sources. About $60 \%$ of total methane emissions originate from anthropogenic activities (IPCC, 2013). Northern hemi- 
spheric sources account for $70 \%$ of global emissions (Kai et al., 2011). Three major processes of methane formation can be distinguished: biogenic methane produced by microbes from organic matter under anaerobic conditions (e.g., in wetlands, ruminants, and waste deposits), thermogenic methane formed in geological processes at elevated temperatures (fossil fuels), and pyrogenic methane produced by incomplete combustion processes, e.g., biomass burning (Kirschke et al., 2013).

The global atmospheric methane burden has more than doubled since 1750. After a decade of near-zero growth (Dlugokencky et al., 2011; Heimann, 2011; Pison et al., 2013), global methane concentrations started to rise again in 2007 (Rigby et al., 2008; Bousquet et al., 2011; Frankenberg et al., 2011; Sussmann et al., 2012; Nisbet et al., 2014). Since then the methane burden has continuously increased with particularly strong growth in 2014 (Nisbet et al., 2015). The growth rate decline before 2007 has been interpreted as approaching a steady state with essentially constant global emissions since the mid-1980s (Dlugokencky et al., 1998). Causes for the renewed increase in global methane levels since 2007 are still poorly understood, which is reflected in, amongst other things, a persistent discrepancy between bottom-up and top-down estimates of methane emissions (e.g., Nisbet and Weiss, 2010; Kirschke et al., 2013).

Recent work provides evidence that there are likely two dominant contributors to the recent methane increase (Kirschke et al., 2013; Nisbet et al., 2014), namely increasing emissions from (i) tropical and boreal wetlands driven by precipitation and temperature anomalies (Dlugokencky et al., 2009; Bousquet et al., 2011) and (ii) growing exploitation of fossil fuels (natural gas, oil, and coal) (e.g., Bergamaschi et al., 2013; see also references in the next paragraph). Even though they introduce interannual variability, biomass burning emissions are found to play only a minor role in explaining the positive long-term methane trend since 2007 (Dlugokencky et al., 2009; Bergamaschi et al., 2013), and global fire emissions slightly decreased between 2000 and 2012 (Giglio et al., 2013). Valuable information for methane source identification is provided by observations of methane isotopes (Dlugokencky et al., 2011; Levin et al., 2012). Since 2007 global methane has become more depleted in ${ }^{13} \mathrm{C}$, which suggests a dominant role of growing ${ }^{12} \mathrm{C}$-rich biogenic emissions, especially from wetlands and ruminants (Nisbet et al., 2014). The recent global average methane growth $\left(\sim 6 \mathrm{ppb} \mathrm{yr}^{-1}\right)$ corresponds to an imbalance between emissions and sinks of about $16 \mathrm{Tg} \mathrm{yr}^{-1}$, which can be best reconciled with three decades of methane (isotopic) observations if attributed to increasing tropical wetland and fossil-fuel-related emissions (Dlugokencky et al., 2015a). Bergamaschi et al. (2013) attribute the renewed increase mainly to growing anthropogenic emissions (which are, however, significantly lower than estimates in bottom-up inventories) superimposed by interannual variations of wetland and biomass burning emissions. Using a GEOS-Chem- model-tagged simulation, W. Bader (personal communication, 2015) suggest that the recent methane increase is dominated by anthropogenic emissions from increased fossil fuel extraction.

Particularly important in this context is the strong increase in US oil and natural gas production starting in the mid2000s (Moore et al., 2014; Wang et al., 2014), which is expected to continue through 2040 (US Energy Information Administration, 2014). This has been facilitated by the development of new extraction techniques (hydraulic fracturing and horizontal drilling), which involve additional fugitive methane emissions during flowback periods compared to conventional techniques (Field et al., 2014; Howarth, 2014). Several studies report that methane emission from this industry is likely underestimated (Karion et al., 2013; Miller et al., 2013; Brandt et al., 2014; Kort et al., 2014; Pétron et al., 2014; Schneising et al., 2014; Turner et al., 2015). Furthermore, the rapid growth of coal exploitation since 2000 - especially in China (OECD/IEA, 2015) - potentially contributes to increasing methane emissions (Bergamaschi et al., 2013; Kirschke et al., 2013).

The major loss process for methane is oxidation by hydroxyl radicals $(\mathrm{OH})$. Trends in the global $\mathrm{OH}$ concentration can have a large impact on the global methane budget (Rigby et al., 2008), but $\mathrm{OH}$ trends are difficult to quantify due to the extremely short lifetime of $\mathrm{OH}$ and its control by many different drivers. IPCC (2013) reports no evidence for an OH trend from 1979 to 2011 based on methyl chloroform measurements. Consistent with this, Kai et al. (2011) infer a stable OH sink from $1998-2005$ using $\delta \mathrm{D}-\mathrm{CH}_{4}$ observations. During 1998-2008, year-to-year changes in $\mathrm{OH}$ concentrations are found to be small (Montzka et al., 2011) and have only a minor impact on methane emissions inferred from inverse modeling (Bousquet et al., 2011).

Overall, evidence suggests that the renewed methane increase since 2007 is mainly caused by a combination of increased tropical wetland emissions and increased emissions from fossil fuel exploitation. However, the relative contribution of these two drivers remains highly uncertain (Kirschke et al., 2013). The goal of this study is to quantify the contribution of increased oil and natural gas production emissions to the renewed methane increase since 2007. Our approach is to use long-term solar Fourier transform infrared (FTIR) measurements of methane in combination with ethane. Ethane $\left(\mathrm{C}_{2} \mathrm{H}_{6}\right)$ is a valuable tracer of thermogenic methane as both emissions are known to be strongly correlated (Aydin et al., 2011; Simpson et al., 2012).

This paper is structured as follows: Section 2 introduces the FTIR observations, retrieval strategies, and trend analysis methods. Results of the long-term trend analysis for columnaveraged ethane and methane are presented in Sect. 3. Subsequently, we develop optimized ethane and methane emission scenarios in Sect. 4 using an atmospheric two-box model. Finally, Sect. 5 gives a summary of results and draws final conclusions. 


\section{Ground-based infrared spectrometric observations}

Time series of column-averaged dry-air mole fractions of methane $\left(\mathrm{XCH}_{4}\right)$ and ethane $\left(\mathrm{XC}_{2} \mathrm{H}_{6}\right)$ are retrieved from long-term solar absorption FTIR measurements. We analyze high-resolution mid-infrared spectra obtained at a northern midlatitude site (Zugspitze, Germany) and a southern midlatitude site (Lauder, New Zealand). Both measurement sites are part of the Network for the Detection of Atmospheric Composition Change (NDACC; www.ndacc.org). Sampled air masses are representative of undisturbed atmospheric background conditions of northern and southern midlatitudes. At the high-altitude observatory Zugspitze $\left(47.42^{\circ} \mathrm{N}\right.$, $10.98^{\circ} \mathrm{E} ; 2964 \mathrm{~m}$ a.s.l.), a Bruker IFS $125 \mathrm{HR}$ spectrometer has been in operation since 1995 (Sussmann and Schäfer, 1997). The FTIR system at Lauder $\left(45.04^{\circ} \mathrm{S}, 169.68^{\circ} \mathrm{E}\right.$; $370 \mathrm{~m}$ a.s.l.) is based on a Bruker IFS $120 \mathrm{HR}$ and was based on a Bruker IFS 120M before 2001 (Rinsland et al., 1998; Zeng et al., 2012).

Retrieval strategies for column-averaged methane and ethane are harmonized for both measurement sites in order to obtain consistent results from Zugspitze and Lauder time series. The methane retrieval follows the strategy developed by Sussmann et al. (2011), which comprises the use of three microwindows and the high-resolution transmission molecular absorption database HITRAN 2000, including its 2001 update (Rothman et al., 2003). This strategy optimizes methane total column precision while minimizing water vapor interference errors, and it is recommended as standard retrieval within NDACC. Mid-infrared NDACC-type methane retrievals are in good agreement with near-infrared FTIR measurements from the Total Carbon Column Observing Network (TCCON; Sussmann et al., 2013; Ostler et al., 2014). For the retrieval of column-averaged ethane we follow the strategy applied in Vigouroux et al. (2012) using two microwindows (2976.66-2976.95, 2983.20-2983.55 $\mathrm{cm}^{-1}$ ), an ethane pseudo-line list (Franco et al., 2015), and first-order Tikhonov regularization. In agreement with the NDACC Infrared Working Group retrieval recommendations (IRWG, 2014), we consider three interfering species (water vapor, ozone, and methane) and choose an a priori volume mixing ratio profile derived from WACCM (Whole Atmosphere Chemistry Model, version 6; Garcia et al., 2007). The a priori influence on methane trend estimates has been shown to be negligible in Sussmann et al. (2013, Table 3). Methane and ethane profile retrievals are performed with the spectral fitting code PROFFIT (PROFile Fit; Hase et al., 2004). The vertical information contained in FTIR retrievals can be characterized by means of degrees of freedom for signal (DOFS). On average, we obtain DOFS $=2.1$ (Zugspitze) and DOFS $=1.8$ (Lauder) for methane retrievals, while for ethane retrievals DOFS $=1.6$ (Zugspitze) and DOFS $=1.2$ (Lauder) is reached. Solar tracker inaccuracies and resulting total column errors during a short period of the Zugspitze long-time record are accounted for using the pointing er- ror correction scheme developed by Reichert et al. (2015). To obtain column-averaged dry-air mole fractions, the retrieved total columns of methane and ethane are divided by the corresponding dry pressure column, which is derived from ground pressure measurements and four times daily pressure-temperature-humidity profiles from the National Center for Environmental Prediction (NCEP) interpolated to FTIR measurement time. Column-averaged dry-air mole fractions provide valuable information for source-sinkinversion studies, as they are independent of variations in surface pressure, solar zenith angle, and humidity (Toon, 2008).

To infer methane and ethane long-term trends from the FTIR time series, we follow the approach by Gardiner et al. (2008). First, seasonal cycles of $\mathrm{XCH}_{4}$ and $\mathrm{XC}_{2} \mathrm{H}_{6}$ time series are removed by fitting and subtracting an intra-annual model (third-order Fourier series). The second step involves a least squares fit of a linear trend to the deseasonalized time series and bootstrap resampling of the residuals to determine the linear trend uncertainty. The trend analysis is performed for two distinct time periods (1999-2006, 20072014), which correspond to methane trend turning points published in earlier work (e.g., Rigby et al., 2008; Dlugokencky et al., 2011; Sussmann et al., 2012; IPCC, 2013).

\section{Results of long-term trend analysis}

Time series of monthly mean methane and ethane columnaveraged dry-air mole fractions above Zugspitze and Lauder are presented in Fig. 1 along with the corresponding deseasonalized time series and linear trend estimates. The results of our trend analysis are compiled in Table 1 and can be summarized as follows: the stagnation of methane growth from 1999 to 2006 and the renewed methane increase since 2007 are consistently observed at Zugspitze and Lauder. The positive trend of column-averaged methane mole fractions since $2007\left(6.2[5.6,6.9] \mathrm{ppb} \mathrm{yr}^{-1}\right.$ at Zugspitze; 6.0 [5.3, 6.7] $\mathrm{ppbyr}^{-1}$ at Lauder) persists until the end of 2014 at both stations and agrees well with the reported global surface methane trend (e.g., Dlugokencky et al., 2011; Nisbet et al., 2014). Annual growth rates of methane as well as for ethane are reported in Appendix A. The long-term trend analysis of column-averaged ethane yields a weak negative trend for the period 1999-2006 with equal magnitudes at Zugspitze $\left(-0.5[-1.0,0.1] \times 10^{-2} \mathrm{ppb} \mathrm{yr}^{-1}\right.$; not statistically significant) and Lauder $\left(-0.4[-0.7,-0.2] \times 10^{-2} \mathrm{ppb} \mathrm{yr}^{-1}\right.$; statistically significant). While this significant negative trend persists at Lauder from 2007 to 2014, at Zugspitze a trend reversal is observed, followed by a statistically significant positive trend of $2.3[1.8,2.8] \times 10^{-2} \mathrm{ppb} \mathrm{yr}^{-1}$ in the period 2007-2014. Due to the high altitude of the Zugspitze observatory (2964 m a.s.l.), the Zugspitze time series represents the background conditions of free tropospheric ethane influenced by long-range transport. The ethane trend turning point at the beginning of 2007 is chosen by analogy with the 

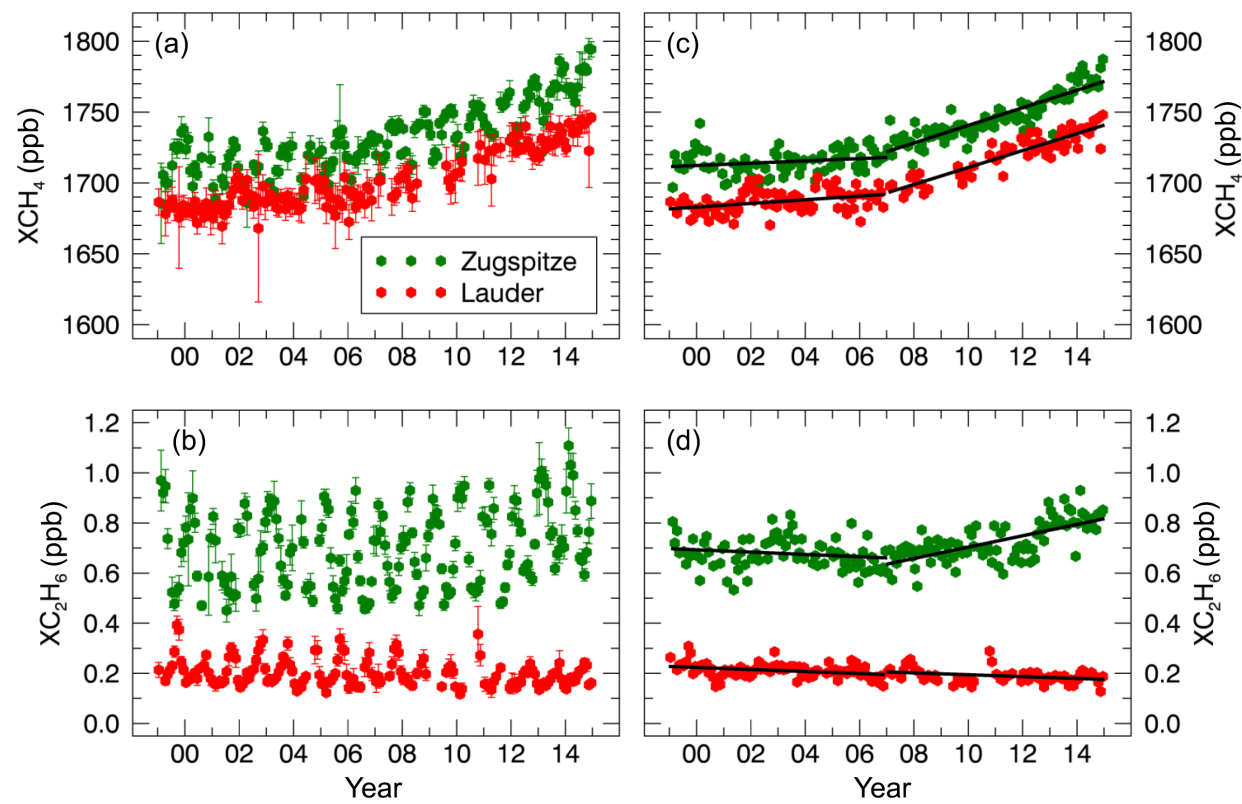

Figure 1. Time series of monthly mean column-averaged dry-air mole fractions of (a) methane and (b) ethane measured at Zugspitze and Lauder. Error bars indicate statistical standard error of $\pm 3 \sigma / \sqrt{n}$ with monthly means calculated from $n$ individual measurements with standard deviation $\sigma$. Deseasonalized time series for (c) methane and (d) ethane are displayed along with linear trend estimates (black lines). See Table 1 for trend magnitudes and uncertainties.

Table 1. Results of trend analysis: linear trend estimates and $95 \%$ confidence intervals.

\begin{tabular}{|c|c|c|c|c|}
\hline & \multicolumn{2}{|c|}{ Trend 1999-2006 (ppb yr $\left.{ }^{-1}\right)$} & \multicolumn{2}{|c|}{ Trend 2007-2014 (ppb yr $\left.{ }^{-1}\right)$} \\
\hline & Zugspitze & Lauder & Zugspitze & Lauder \\
\hline Methane & $0.8[0.0,1.6]$ & $1.3[0.6,1.9]$ & $6.2[5.6,6.9]$ & $6.0[5.3,6.7]$ \\
\hline Ethane $\left(\times 10^{-2}\right)$ & $-0.5[-1.0,0.1]$ & $-0.4[-0.7,-0.2]$ & $2.3[1.8,2.8]$ & $-0.4[-0.6,-0.1]$ \\
\hline $\mathrm{IHG}-\mathrm{XCH}_{4}^{\mathrm{a}}$ & \multicolumn{2}{|c|}{$-0.6[-1.9,0.5]$} & \multicolumn{2}{|c|}{$0.7[-0.4,1.8]$} \\
\hline $\mathrm{IHG}-\mathrm{XC}_{2} \mathrm{H}_{6}^{\mathrm{b}}\left(\times 10^{-2}\right)$ & \multicolumn{2}{|c|}{$0.1[-0.5,0.7]$} & \multicolumn{2}{|c|}{$2.7[2.1,3.3]$} \\
\hline
\end{tabular}

${ }^{a}$ Interhemispheric gradient (IHG) of methane, defined as difference between northern and southern high-latitudinal averages.

${ }^{\mathrm{b}}$ Interhemispheric gradient of ethane.

methane trend periods. We found this choice to be corroborated by the 2-year running mean of the monthly $\mathrm{XC}_{2} \mathrm{H}_{6}$ time series, which reveals a minimum in October 2006.

A sensitive tool to locate changing emissions is the study of trends in spatial gradients of methane and ethane. We define the interhemispheric gradient (IHG) as the difference between northern and southern high-latitude averages $\left(30-90^{\circ} \mathrm{N} / \mathrm{S}\right)$ of methane (IHG- $\left.\mathrm{XCH}_{4}\right)$ and ethane (IHG$\mathrm{XC}_{2} \mathrm{H}_{6}$ ), respectively. The IHG is calculated from the difference of Zugspitze and Lauder monthly mean time series, assuming that Zugspitze (Lauder) observations are representative of the northern (southern) high-latitude $\mathrm{XCH}_{4}$ and $\mathrm{XC}_{2} \mathrm{H}_{6}$ average. This assumption is supported by the following argumentation: ethane is approximately well-mixed in high northern and southern latitudes (Aydin et al., 2011) as its lifetime of 2.6 months (Xiao et al., 2008) exceeds zonal mixing timescales of about 2 weeks (Williams and Koppmann, 2007). Methane has an even longer lifetime of about 9 years (Prather et al., 2012) and is therefore well-mixed north of $30^{\circ} \mathrm{N}$ and in the Southern Hemisphere (Simpson et al., 2002; Saito et al., 2012). Trend analysis reveals no significant trend for IHG- $\mathrm{XCH}_{4}$ in both time periods considered, while the trend of IHG- $\mathrm{XC}_{2} \mathrm{H}_{6}$ is also statistically insignificant in the beginning but changes to a significant positive trend after 2007 (see Table 1).

We can interpret our findings on the trend behavior of ethane and its interhemispheric gradient in relation to methane emissions as follows. Major ethane sources are biomass burning, biofuel use, and fossil fuel fugitive emissions from the production and transport of coal (coal-bed gas), oil (associated gas), and natural gas (unassociated gas). About $80 \%$ of global ethane emissions are located in the 
Northern Hemisphere (Xiao et al., 2008). In contrast to methane, ethane cannot completely mix over both hemispheres, as its lifetime is short compared to the interhemispheric exchange time of approximately 1 year (Tans, 1997; Williams and Koppmann, 2007; Aydin et al., 2011). Ethane concentrations have continuously declined since the 1980s, which can be explained by reduced fossil-fuel-related emissions (Aydin et al., 2011; Simpson et al., 2012; Helmig et al., 2014). Negative ethane trends for 1996-2006 are also reported by Angelbratt et al. (2011) from FTIR observations at four European NDACC stations. The recent ethane trend reversal identified at the Zugspitze observatory is also observed at the high-altitude NDACC station of Jungfraujoch, Swiss Alps (Franco et al., 2015). Furthermore, longterm in situ measurements in the US show increasing ethane concentrations over the past years linked with increasing natural gas production (Vinciguerra et al., 2015). Overall, these time series point to a recent ethane increase in the Northern Hemisphere. Consistent with our observations in Lauder, a continuing ethane decline is observed at two other NDACC FTIR stations in the Southern Hemisphere: in Arrival Heights, Antarctica (Zeng et al., 2012), the total-column ethane trend is significantly negative for the period 19992006 and weakly negative but not significant in the period 2007-2014. A similar trend behavior has been observed at Wollongong, Australia (N. Jones, personal communication, 2015). The significant positive trend of IHG- $\mathrm{XC}_{2} \mathrm{H}_{6}$ for 2007-2014 suggests increasing ethane emissions in the Northern Hemisphere, where most fossil-fuel-related ethane sources are located. Using ethane as a tracer for thermogenic methane emissions, the presented simultaneous increase in methane and ethane in the Northern Hemisphere since 2007 points to a potential contribution of thermogenic methane sources to the methane burden increase since 2007.

\section{Contribution of oil and natural gas emissions to renewed methane increase}

\subsection{Ethane-to-methane ratio}

Thermogenic and biogenic methane sources can be separated using their ethane-to-methane emission ratios (Schoell, 1980). While there are no associated ethane emissions during microbial methanogenesis, ethane is emitted together with methane from thermogenic sources, i.e., primarily from fossil fuel extraction. The molar ethane-to-methane ratio (EMR) is larger than $1.0 \%$ for largely thermogenic methane sources (Kang et al., 2014; Yacovitch et al., 2014), whereas biogenic sources are characterized by EMR values below $0.1 \%$ (Taylor et al., 2000; Jackson et al., 2014). For atmospheric measurements in spatial and temporal proximity to an emission source, the ethane-to-methane ratio of this source $\left(\mathrm{EMR}_{\text {source }}\right)$ can be determined from the linear regression slope in a scatterplot of ethane against methane mole fractions. This technique has been applied in several studies to compare ethane-to-methane ratios of atmospheric measurements with ratios in nearby natural gas pipelines (e.g., Wennberg et al., 2012).

Scatterplots of deseasonalized monthly mean $\mathrm{XC}_{2} \mathrm{H}_{6}$ and $\mathrm{XCH}_{4}$ at Zugspitze and Lauder are shown in Fig. 2a for the period 1999-2006 and in Fig. 2b for the period 2007-2014. All results of the linear regression and correlation analysis are summarized in Table 2. We find a significant ethanemethane correlation for 2007-2014 data at Zugspitze with a coefficient of determination $\left(R^{2}\right)$ of 0.44 , while no significant ethane-methane correlation is found for the 1999-2006 period at Zugspitze and for either period at Lauder. The regression slope for the 2007-2014 data at Zugspitze amounts to $0.31 \pm 0.07 \%$ (uncertainty given on $2 \sigma$ level) and is significantly larger than $0.1 \%$. In contrast, the slopes do not significantly differ from zero for 1999-2006 at Zugspitze and for either period at Lauder.

As the measurements analyzed here represent background conditions (i.e., are not observed in close proximity to sources), it is not possible to directly infer the ethaneto-methane ratio of the source from the regression slope. Our methane and ethane time series measured at remote sites are subject to long-term trends of emissions, photochemical loss (reaction with $\mathrm{OH}$ ), and mixing during atmospheric transport. Ethane-to-methane ratios (EMR background) determined from the regression slopes can therefore differ significantly from the original emission ratio (Borbon et al., 2013; Yokelson et al., 2013) and will likely be smaller due to the different lifetimes of methane and ethane (Wang and Zeng, 2004; Parrish et al., 2007). Nevertheless, a rough estimate of the source ethane-to-methane ratio can be obtained using a simple heuristic model: in a wellstirred reactor, emission pulses are instantaneously mixed in the troposphere followed by first-order chemical loss in the well-mixed troposphere (Parrish et al., 2007). The source ethane-to-methane ratio can then be inferred from the measured $\mathrm{EMR}_{\text {background }}$ and the rate constants for the reaction with $\mathrm{OH}\left(k_{\text {ethane }}=1.83 \times 10^{-13} \mathrm{~cm}^{3}\right.$ molecule $^{-1} \mathrm{~s}^{-1}$ and $k_{\text {methane }}=3.68 \times 10^{-15} \mathrm{~cm}^{3}$ molecule ${ }^{-1} \mathrm{~s}^{-1}$; Sander et al., 2011):

$\mathrm{EMR}_{\text {source }}=\mathrm{EMR}_{\text {background }} \times k_{\text {ethane }} / k_{\text {methane }}$.

This simplification is applicable as methane and ethane are long-lived compared to the period of about 30 days required for the complete dispersion of an emission pulse throughout the hemispheric troposphere (Parrish et al., 2007). As a first approximation, such long-lived trace gases can mix within a hemisphere, and details of transport and mixing become unimportant (Stohl et al., 2002), especially if looking at monthly or annual means. Using the simplifying assumption of a constant emission ratio during 2007-2014 and applying the well-stirred reactor model, the $2 \sigma$-uncertainty range of the regression slope inferred from Zugspitze 2007-2014 

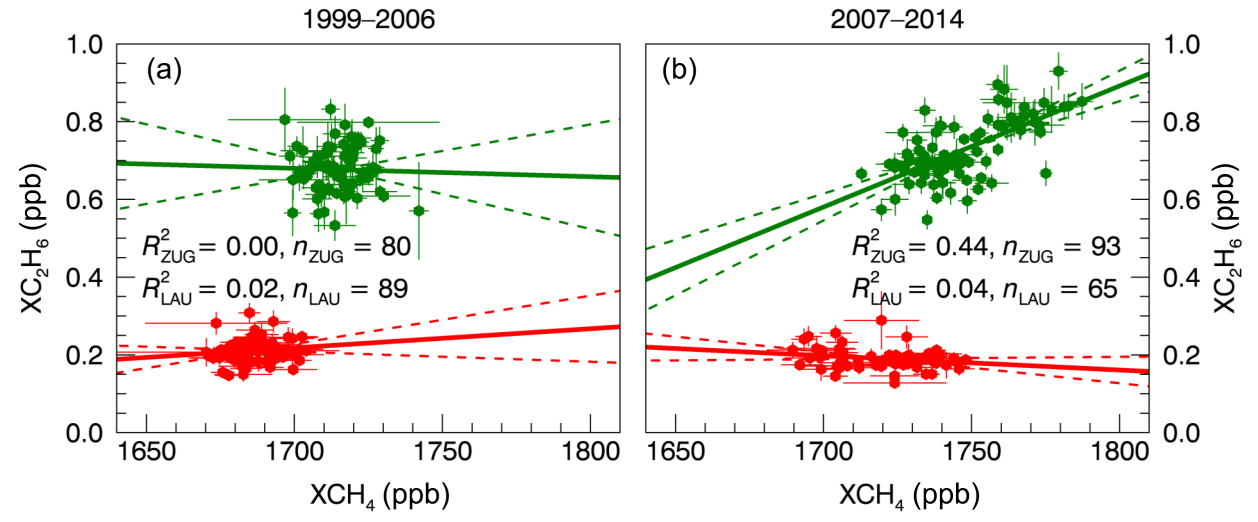

Figure 2. Scatterplots of monthly mean column-averaged ethane and methane derived from deseasonalized time series at Zugspitze (green) and Lauder (red) for the time periods of (a) 1999-2006 and (b) 2007-2014. Solid (dashed) lines show linear regression results (uncertainty on $2 \sigma$ level).

Table 2. Ethane-methane correlation analysis and linear regression results.

\begin{tabular}{lrrrrrr}
\hline & \multicolumn{2}{c}{$1999-2006$} & & \multicolumn{2}{c}{ 2007-2014 } \\
\cline { 2 - 3 } \cline { 5 - 6 } & Zugspitze & Lauder & & Zugspitze & Lauder \\
\hline Number of monthly means $n$ & 80 & 89 & & 93 & 65 \\
Pearson's correlation coefficient $R$ & -0.03 & 0.14 & & 0.66 & -0.21 \\
Quality measure $R \times \sqrt{(n-2) /\left(1-R^{2}\right)}$ & -0.27 & 1.31 & & 8.45 & -1.71 \\
$t$ value for 99\% confidence level & 2.64 & 2.63 & & 2.63 & 2.66 \\
Significant correlation $(99 \%$ confidence)? & no & no & & yes & no \\
Regression slope & $-0.02 \%$ & $0.05 \%$ & & $0.31 \%$ & $-0.04 \%$ \\
Uncertainty $( \pm 2 \sigma)$ & $\pm 0.16 \%$ & $\pm 0.08 \%$ & & $\pm 0.07 \%$ & $\pm 0.04 \%$ \\
\hline
\end{tabular}

data $(0.31 \pm 0.07 \%)$ transfers to a source ethane-to-methane ratio ranging from 12 to $19 \%$. This is within the EMR value range of $1-25 \%$ known to be typical for oil and gas production emissions (Xiao et al., 2008), while coal mining emissions exhibit lower EMR values of below $1 \%$ (Xiao et al., 2008; Schwietzke et al., 2014).

The derived EMR range (12-19\%) would also be in line with a potential contribution from biomass burning emissions, which are associated with EMR values of 4-18\% (Akagi et al., 2011). However, there are no indications for a strong positive trend in biomass burning emissions during 2007-2014 that could have caused the observed ethane increase since 2007: biomass burning emissions from the Global Fire Emission Database GFED4s (van der Werf et al., 2010; Giglio et al., 2013) modestly decrease during 20072014 (5-year averages of global $\mathrm{CH}_{4}$ biomass burning emissions amount to $14.2 \mathrm{Tg} \mathrm{yr}^{-1}$ for 2007 and $13.4 \mathrm{Tg} \mathrm{yr}^{-1}$ for 2012). Furthermore, columns of the biomass burning tracer CO do not exhibit a significant trend during 2007-2014 $\left(-4.6[-10.0,1.0] \times 10^{15}\right.$ molecule $\mathrm{cm}^{-2} \mathrm{yr}^{-1} ; 95 \%$ confidence interval) as determined from the Zugspitze FTIR time series. Consistent results are obtained at the high-altitude NDACC FTIR station of Jungfraujoch (Swiss Alps, $46.5^{\circ} \mathrm{N}$ ), where neither biomass burning tracer $\mathrm{CO}$ and $\mathrm{HCN}$ presents an upturn in this time period (Franco et al., 2015). The 20072014 trend of CO and HCN total columns at Jungfraujoch amounts to $-5.2[-10.1,-0.3] \times 10^{15}$ molecule $\mathrm{cm}^{-2} \mathrm{yr}^{-1}$ and $0.003[-0.029,0.033] \times 10^{15}$ molecule $\mathrm{cm}^{-2} \mathrm{yr}^{-1}$, respectively (determined via bootstrap method from Jungfraujoch data available from the NDACC database; E. Mahieu, personal communication, 2015; the CO time series is an extension of Dils et al., 2011).

In summary, methane and ethane time series are significantly correlated for the period from 2007 to 2014 at Zugspitze. From the regression slope, we derive a source emission ratio range which corresponds to thermogenic methane emissions from oil and natural gas sources. In contrast, we do not find a significant ethane-methane correlation for Zugspitze data during 1999-2006 and for Lauder data in both periods. Consequently, we draw the inference that thermogenic methane fugitive emissions from fossil fuel production and distribution have significantly contributed to the renewed methane increase since 2007. 


\subsection{Optimized emission scenarios and thermogenic methane increase}

To quantify the contribution of thermogenic methane emissions from the growing oil and natural gas industry to the renewed methane increase since 2007, we proceed as follows: first we infer the ethane emission change necessary to explain the observed positive ethane trend at Zugspitze since 2007 using an atmospheric two-box model. These additional ethane emissions not included in ethane emission inventories are then fully attributed to growing emissions from oil and natural gas exploitation. As a second step we use a reasonable ethane-to-methane ratio for oil and natural gas emissions to quantify the associated thermogenic methane emission increase and relate it to the total methane emission increase during 2007-2014.

Hemispheric column-averaged methane and ethane time series are simulated with the help of a two-box atmospheric model based on the work of Aydin et al. (2011) and Kai et al. (2011). The model represents two well-mixed hemispheres, each with a distinct methane and ethane source and sink, which are interconnected by interhemispheric exchange with a timescale of about 1 year. A brief outline of the two-box model is given in Appendix B together with an overview of the applied model parameters. The two-box model enables the linkage of the 2007-2014 trend observations at Zugspitze and Lauder with the respective emission histories of ethane and methane. Initial methane emissions are taken from the latest IPCC report (IPCC, 2013). About $70 \%$ of global methane emissions are located in the Northern Hemisphere (Kai et al., 2011). Initial global ethane emissions are compiled from various emission inventories (see details in Appendix B) for three source categories: fossil-fuelrelated emissions, biomass burning, and biofuel use emissions. Overall, about $80 \%$ of global ethane emissions are located in the Northern Hemisphere (Xiao et al., 2008). This northern hemispheric emission fraction $\left(f_{\mathrm{N}}\right)$ is distinct for individual ethane sources as they exhibit different latitudinal distributions (i.e., $f_{\mathrm{N}}$ equals $95,90,81$, and $53 \%$ for emissions from oil and natural gas, coal, biofuel use, and biomass burning, respectively; see Table B2). Major ethane sources in the Southern Hemisphere are interhemispheric transport and biomass burning (Xiao et al., 2008).

Our knowledge for developing accurate initial emission inventories is incomplete; therefore, simulated and observed time series of atmospheric methane and ethane mole fractions are likely to diverge. In order to reconstruct the observed 2007-2014 trend of $\mathrm{XCH}_{4}$ and $\mathrm{XC}_{2} \mathrm{H}_{6}$ using the twobox atmospheric model, we developed an optimized emission scenario by minimizing the difference between modeled and observed trend at Zugspitze. The modeled trend is determined by linear regression from the modeled annual methane or ethane time series. Annual global emissions from 2007 to 2014 are optimized by adding a linear emission growth since 2007 to the initial emission history:

$$
E_{\mathrm{CH}_{4}, \text { tot, opt }}(y)=E_{\mathrm{CH}_{4}, \text { tot, ini }}(y)+\left(y-y_{0}\right) \times s_{\mathrm{CH}_{4}}
$$

and

$$
\begin{aligned}
E_{\mathrm{C}_{2} \mathrm{H}_{6}}, \text { oil \& gas, opt }(y)= & E_{\mathrm{C}_{2} \mathrm{H}_{6}, \text { oil \& gas, ini }}(y) \\
& +\left(y-y_{0}\right) \times s_{\mathrm{C}_{2} \mathrm{H}_{6}} .
\end{aligned}
$$

Here, $E_{\mathrm{CH}_{4} \text {, tot, ini }}(y)$ and $E_{\mathrm{C}_{2} \mathrm{H}_{6}}$, oil \& gas, ini $(y)$ are the initial annual global emissions of methane and the initial emissions of ethane from the oil and gas industry in $\mathrm{Tg} \mathrm{yr}^{-1}$, respectively. Optimized annual methane and ethane emissions

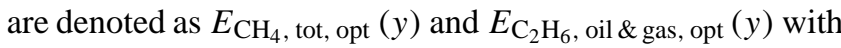
year $y \in[2007,2014]$, reference year $y_{0}=2006$, and linear emission growth rate $s_{\mathrm{CH}_{4}}$ for methane and $s_{\mathrm{C}_{2} \mathrm{H}_{6}}$ for ethane. The choice of a linear emission increase in the model is motivated by largely linearly growing fossil fuel production, which implies a linear ethane emission increase from this sector. Additionally, the positive ethane trend since 2007 can only be reproduced by a continuous emission increase, as the relatively short lifetime of ethane prevents it from accumulating over the years. In contrast, the methane increase from 2007 to 2014 could basically be simulated with a step change in methane emissions in 2007 due to its longer atmospheric lifetime. At least the thermogenic part of methane emissions has to increase linearly as associated with the linear ethane emission increase. This procedure provides us with an estimate for the total methane emission increase $\Delta E_{\mathrm{CH}_{4} \text {, tot, opt }}$ from 2007 to 2014, causing the observed positive methane trend, as well as an estimate of the overall increase in oil and

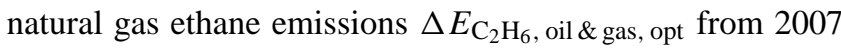
to 2014 necessary to explain the ethane increase observed at Zugspitze. The uncertainty of the inferred optimized emis-

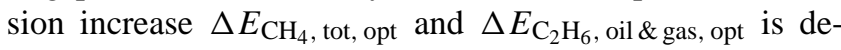
termined using a perturbation approach: the lower (upper) bound estimate is inferred from a separate optimization with maximized (minimized) model trend, which is obtained by setting all two-box model parameters to the lower or upper bound of their uncertainty range (see Appendix B, Tables B1 and B2).

The contribution $C$ of oil and natural gas emissions to the recent methane increase since 2007 can be inferred as the ratio of the methane emission increase attributed to the ethane oil and gas emission increase over the period 2007-2014 and the total methane emission increase from 2007 to 2014:

$C=\frac{\Delta E_{\mathrm{C}_{2} \mathrm{H}_{6}, \text { oil \& gas, opt }} \times \mathrm{EMR}^{-1} \times\left(M_{\mathrm{CH}_{4}} / M_{\mathrm{C}_{2} \mathrm{H}_{6}}\right)}{\Delta E_{\mathrm{CH}_{4}, \text { tot }, \text { opt }}}$.

Here, EMR is the molar ethane-to-methane ratio and $M_{\mathrm{CH}_{4}} / M_{\mathrm{C}_{2} \mathrm{H}_{6}}$ the molar mass ratio of methane and ethane $\left(16 \mathrm{~g} \mathrm{~mol}^{-1} / 30 \mathrm{~g} \mathrm{~mol}^{-1}\right)$. The uncertainty range $(2.5 \mathrm{th}-$ 97.5th percentile) of the oil and natural gas contribution $C$ is determined using a Monte Carlo simulation with $10^{6}$ random samples from a normal distribution of EMR and from lognor-

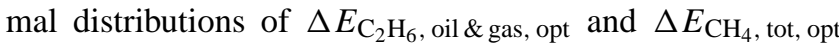


(parameter ranges are interpreted as $3 \sigma$ intervals of the distributions). We consider three emission scenarios characterized by a distinct EMR range. Our reference scenario (scenario 1) includes a combination of oil and natural gas emissions with an EMR range of $7.0-16.2 \%$, which is determined by the natural gas emission upper bound EMR and the oil emission lower bound EMR given in Schwietzke et al. (2014). Two more extreme scenarios are considered: either complete attribution to oil-related emissions with an EMR range of 16.2-31.4\% (scenario 2) or complete attribution to natural gas sources with an EMR range of 4.4-7.0\% (scenario 3). These EMR ranges are taken from Schwietzke et al. (2014) and are originally given as mass-based methaneto-ethane ratios (MER) in $\mathrm{Tg} \mathrm{CH}_{4}\left(\mathrm{Tg} \mathrm{C}_{2} \mathrm{H}_{6}\right)^{-1}$. The corresponding MER ranges of the presented emission scenarios amount to MER $=[3.3,7.6]$ (scenario 1$), \operatorname{MER}=[1.7$, 3.3] (scenario 2), and MER $=[7.6,12.1]$ (scenario 3). For reasons of consistency with Sect. 4.1, we use molar EMR ranges here, which can be derived as $\mathrm{EMR}=\mathrm{MER}^{-1} \times$ $\left(M_{\mathrm{CH}_{4}} / M_{\mathrm{C}_{2} \mathrm{H}_{6}}\right) \times 100 \%$.

The emission optimization results obtained with the twobox model can be summarized as follows: we find a global

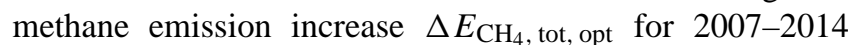
of $24-45 \mathrm{Tg} \mathrm{yr}^{-1}$ and an ethane oil and gas emission in-

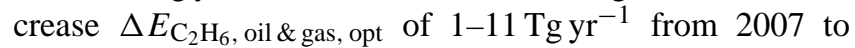
2014, which are necessary to simulate the observed positive methane and ethane trend in this period. For the considered emission scenarios, the oil and natural gas emission contribution to the renewed methane increase is within the following ranges (95\% confidence interval): $C=[39,160] \%$ for scenario 1 (oil and gas emission combination), $C=[18,72] \%$ for scenario 2 (only oil-related emissions), and $C=[73$, 280] \% for scenario 3 (pure natural gas sources). The lower boundary of these confidence intervals provides an estimate for the minimum contribution of oil and natural gas emission to the renewed methane increase (upper boundaries greater than $100 \%$ are physically not meaningful and not further considered). As oil and natural gas sources cannot be distinguished using the approach presented here, and reliable information on the ratio of oil to natural gas emissions is missing, a plausible EMR for combined oil and natural gas emissions has to be assumed, which is represented in scenario 1 . In contrast, scenario 2 and 3 are only considered as limiting cases and should not be perceived as realistic settings.

Two-box model results are presented in Fig. 3: modeled annual mean time series of methane (Fig. 3a) and ethane (Fig. 3b) are shown for high northern latitudes (HNL: 30$90^{\circ} \mathrm{N}$ ) and for high southern latitudes (HSL: $30-90^{\circ} \mathrm{S}$ ). Figure $3 \mathrm{c}$ depicts prior global methane and ethane emission inventories as well as the optimized emission scenario from 2007 to 2014 including optimized total methane emissions and optimized ethane emissions from oil and natural gas production. As observations at Zugspitze and Lauder are representative of high-latitudinal averages, modeled hemispheric ethane averages have to be related to HNL and HSL averages,
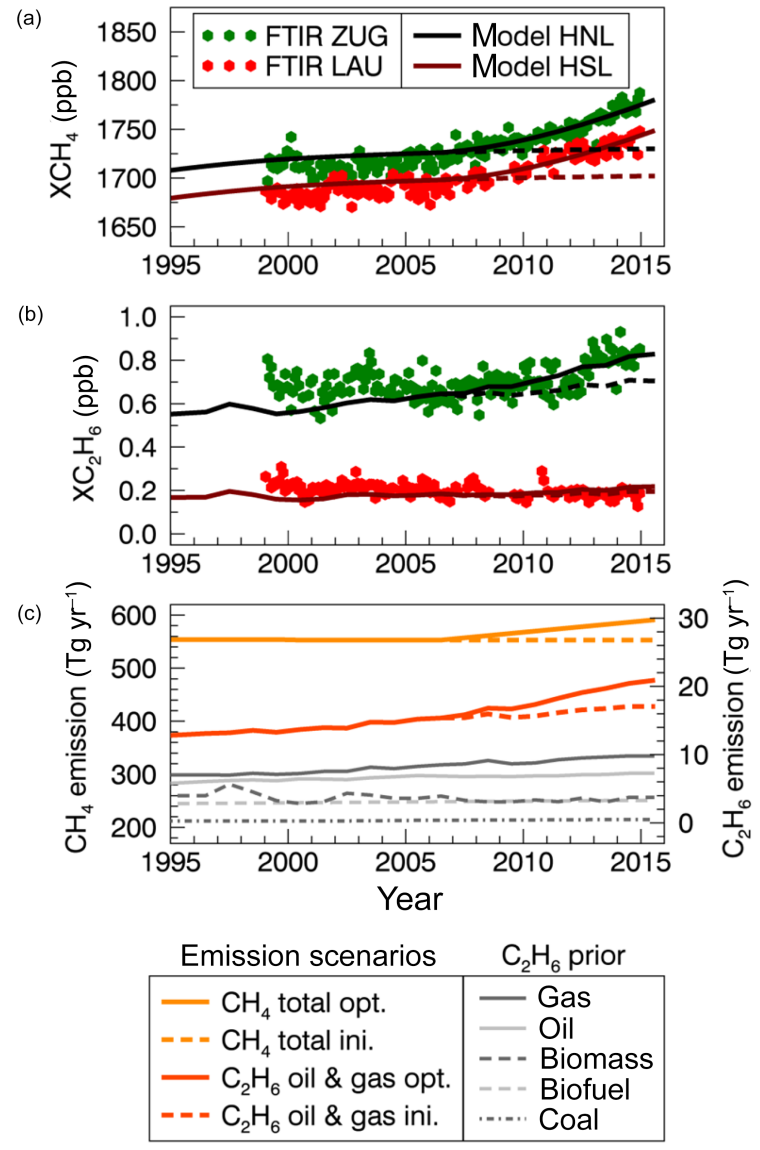

Figure 3. Methane and ethane two-box model: (a) monthly mean column-averaged methane and (b) ethane from Zugspitze and Lauder FTIR observations. Modeled annual means of $\mathrm{XCH}_{4}$ and $\mathrm{XC}_{2} \mathrm{H}_{6}$ are shown for high northern and southern latitudes (HNL, HSL) after emission optimization (solid lines) and with prior emissions (dashed lines). An overall offset is applied to the modeled time series to fit the observed average for 2007-2014. (c) Emission scenario for 2007-2014: optimized global emissions of methane (" $\mathrm{CH}_{4}$ total opt.", left $y$ axis) and ethane from oil and natural gas sources (" $\mathrm{C}_{2} \mathrm{H}_{6}$ oil \& gas opt.", right $y$ axis). For comparison, the corresponding initial emission histories are displayed along with prior ethane emissions of all considered source categories.

where relatively short-lived ethane is reasonably well-mixed (Simpson et al., 2012). Each ethane source contributes with different efficiency to high-latitude ethane levels as concentrated in different latitudes (fossil fuel and biofuel emissions in northern midlatitudes, biomass burning primarily in the tropics). We use the response ratios of HNL or HSL averages to changes in hemispheric means as determined in Aydin et al. (2011). In contrast to the case of ethane, methane has a much longer atmospheric lifetime and therefore a relatively small interhemispheric gradient of about $4 \%$ (Kai et al., 2011) compared to $70 \%$ for ethane (Simpson et al., 2012). Consequently, the latitudinal gradient between high latitudes and the tropics is relatively weak compared to ethane. This 
is reflected in the ratio of HNL to hemispheric methane averages, which amounts to 1.02 (derived from Dlugokencky et al., 2015b) and is much smaller than this ratio for ethane (1.38; derived from Simpson et al., 2012). Therefore, we assume modeled hemispheric methane averages to be representative of high-latitudinal averages as a first approximation in the two-box model. In particular, this assumption seems to be valid for methane as no distinction is made between different sources with potentially different latitudinal distributions.

Considering only oil and natural gas ethane emissions in the emission optimization implies attributing all additional ethane emissions compared to prior emissions to increasing oil and natural gas sources. This approximation can be justified, as the long-term variability of ethane is dominated by changes in its fossil fuel sources (Aydin et al., 2011). Furthermore, no evidence points to a long-term increase in biomass burning or biofuel use emissions sufficiently strong to explain the observed ethane trend (see discussion in Sect. 4.1 and Appendix A). The biomass burning emission inventory applied in this study (GFED4s) is based on satellite-derived estimates of burned area together with biogeochemical modeling (van der Werf et al., 2010). Such top-down emission inventories can be considered to be more reliable than bottomup inventories (Nisbet and Weiss, 2010), such as the applied fossil fuel emission inventory (Schwietzke et al., 2014). Furthermore, the inventory of Schwietzke et al. (2014) is available only until 2011 and extrapolated to 2012-2014 using global fossil fuel production data (see Appendix B), while no extrapolation is required for GFED4s as emissions in the year 2014 are included. Coal mining emissions may have significantly contributed to the methane increase since 2007 (Bergamaschi et al., 2013) but play a minor role in the ethane emission increase which cannot be fully explained by coalrelated emissions. Our approach using ethane as a constraint is not fully suitable to quantify the methane emission increase related to coal mining, as coal emissions are characterized by small EMR values of $0.01-1.07 \%$ (MER $=50-5000$ ) (Xiao et al., 2008; Schwietzke et al., 2014) with a substantial contribution of biogenic methane emissions (EMR $<0.1 \%$ ) that have almost no associated ethane emissions. Nevertheless, we account for the global coal production growth of $22 \%$ since 2007 (US Energy Information Administration, 2015) in the applied prior ethane emissions from coal mining (see Fig. 3c).

Our two-box model estimate of the total methane emission increase from 2007 to $2014\left(\Delta E_{\mathrm{CH}_{4} \text {, tot, opt }}=24-45 \mathrm{Tg} \mathrm{yr}^{-1}\right)$ agrees well with literature estimates of the methane emission change in 2007-2014. Bergamaschi et al. (2013) report a methane emission increase by $16-20 \mathrm{Tg} \mathrm{yr}^{-1}$ for $2007-$ 2010 compared to 2003-2005. Kirschke et al. (2013) find a methane emission increase of $17-22 \mathrm{Tg} \mathrm{yr}^{-1}$ from 2005 to 2010 , which is probably low-biased due to few observations at the end of the 20105 -year average. A methane emission increase of $22 \pm 18 \mathrm{Tg} \mathrm{yr}^{-1}$ between 2005 and 2009 (3-year average) is derived from emissions estimated with
CarbonTracker- $\mathrm{CH}_{4}$ (Bruhwiler et al., 2014; available at www.esrl.noaa.gov/gmd/ccgg). All of these estimates from the literature can be extrapolated to the period 2007-2014 assuming constant emission growth over this period. Estimates of the overall emission increase from 2007 to 2014 amount to $25-31,24-31$, and $20-56 \mathrm{Tg} \mathrm{yr}^{-1}$ as extrapolated from the estimates in Bergamaschi et al. (2013), Kirschke et al. (2013), and Bruhwiler et al. (2014), respectively. These estimates of an overall emission increase for the period 2007-2014 are defined as the difference between global methane emissions in 2014 and in 2007 assuming linear emission growth over this period. These numbers are to be distinguished from an instantaneous source-sink imbalance in a certain year derived from the annual methane growth rate in that year using an atmospheric one-box model and a mole-fraction-to-mass conversion factor (Dlugokencky et al., 1998). According to this approach a methane growth rate of about $6 \mathrm{ppb} \mathrm{yr}^{-1}$ can be translated to a source-sink imbalance of $16 \mathrm{Tg} \mathrm{yr}^{-1}$ (Dlugokencky et al., 2015a). A corresponding emission step change in 2007 implemented in the two-box model could be used to simulate the observed methane increase since 2007 (which is not the case for ethane). After the step change a new steady state is approached on a timescale comparable to the lifetime of methane.

We have shown above that the observed positive ethane trend in the Northern Hemisphere can be explained by linearly increasing ethane emissions from oil and natural gas extraction (emission increase from 2007 to 2014 of $\left.\Delta E_{\mathrm{C}_{2} \mathrm{H}_{6} \text {, oil \& gas, opt }}=1-11 \mathrm{Tg} \mathrm{yr}^{-1}\right)$. The associated oil and natural gas methane emission increase for 2007-2014 can be determined using a realistic ethane-to-methane ratio. We find a significant contribution of growing methane emissions from oil and natural gas extraction to the total methane emission increase since 2007 estimated with the two-box model. Using Monte Carlo simulation we determine an oil and natural gas emission contribution of at least 39\% (95\% confidence level) for the reference scenario with an EMR range of $7.0-16.2 \%$ and of at least $18 \%$ for the highest EMR scenario valid for pure oil emissions.

\section{Summary and conclusions}

In this study, we demonstrate that long-term observations of column-averaged ethane within the NDACC FTIR framework provide a valuable constraint on the source attribution of methane emission changes. We present harmonized time series of column-averaged dry-air mole fractions of methane and ethane for Zugspitze $\left(47^{\circ} \mathrm{N}, 11^{\circ} \mathrm{E}\right)$ and Lauder $\left(45^{\circ} \mathrm{S}, 170^{\circ} \mathrm{E}\right)$, representative of high northern and southern latitude background conditions. Long-term trend analysis reveals consistent changes of methane concentrations in both hemispheres: the period of stagnating methane growth from 1999 to 2006 is followed by a renewed methane in- 
crease since 2007 continuing through 2014. The 2007-2014 period is characterized by a growth in column-averaged methane of $6.2[5.6,6.9] \mathrm{ppb} \mathrm{yr}^{-1}$ at Zugspitze and $6.0[5.3$, 6.7] $\mathrm{ppb} \mathrm{yr}^{-1}$ at Lauder (given as $95 \%$ confidence intervals). In the case of ethane, a trend reversal marked by a significant positive trend of $2.3[1.8,2.8] \times 10^{-2} \mathrm{ppb} \mathrm{yr}^{-1}$ since 2007 is observed in northern high latitudes at Zugspitze, in contrast to a continuing decline $\left(-0.4[-0.6,-0.1] \times 10^{-2} \mathrm{ppb} \mathrm{yr}^{-1}\right)$ in southern high latitudes.

For the time period of renewed methane increase (20072014) we were able to derive evidence that the underlying overall source ethane-to-methane ratio corresponds to typical emission ratios of oil and gas production sources (assuming a constant emission ratio for this time period and well-mixed hemispheres). We presented optimized global methane and ethane emission scenarios for 2007-2014 consistent with our trend observations at Zugspitze and Lauder. An ethane emission increase of $1-11 \mathrm{Tg} \mathrm{yr}^{-1}$ (total increase between 2007 and 2014) from the oil and natural gas sector is necessary to reconstruct the positive ethane trend at Zugspitze. We determined the associated methane emission increase using three different assumptions of ethane-to-methane ratios: oil and gas source mixture with EMR $=7.0-16.2 \%$ (scenario 1 ), oil sources with EMR $=16.2-31.4 \%$ (scenario 2), and natural gas sources with EMR $=4.4-7.0 \%$ (scenario 3). The derived methane emission increase for 2007-2014 constrained by the ethane emission history can then be related to the total methane emission increase of $24-45 \mathrm{Tg} \mathrm{yr}^{-1}$, which is necessary to explain the observed methane trend from 20072014. From this, we found a significant contribution of emissions from oil and natural gas production to the renewed methane increase since 2007. At $95 \%$ confidence level, the increase in these thermogenic methane emissions accounts for at least $39 \%$ (scenario 1, assuming a mixture of oil and natural gas sources), at least $18 \%$ (scenario 2, assuming pure oil sources), or at least $73 \%$ (scenario 3, assuming pure gas sources) of the renewed methane increase.

For verification of our results, more studies are needed using full 3-D chemical transport models to simulate atmospheric methane and ethane trends. Our findings indicate the direction for further source attribution studies of the renewed methane increase and provide basic knowledge for developing effective methane emission reduction strategies. 


\section{Appendix A: Annual growth rates}

In addition to the monthly mean time series and linear trend estimates for column-averaged methane and ethane at Zugspitze and Lauder in Sect. 3 (Fig. 1), we present annual growth rates for methane and ethane in Fig. A1. Following the approach of Kirschke et al. (2013), annual growth rates are calculated as the difference of annual mean mole fractions between the considered and the previous year. Uncertainties are determined as quadratic sum of the standard errors of these two annual means. Additionally, annual running mean growth rates for each month are computed analogously to the approach of Rigby et al. (2008). Interannual variability of annual growth rates is lower in the 2007-2014 period compared to the 1999-2006 period in all cases with the exception of the Lauder ethane time series (low variability over the full time period). In the 2007-2014 period methane growth rates at Zugspitze and Lauder are generally positive and increasing, while oscillating around zero before. Consistent with the results of Nisbet et al. (2015), we observe an extraordinarily high methane growth rate at Zugspitze in 2014 $\left(13.1 \mathrm{ppb} \mathrm{yr}^{-1}\right)$. In contrast, methane and ethane growth rates at Lauder as well as ethane growth at Zugspitze are not particularly high in 2014.

Even if biomass burning emissions do not show a longterm trend (see Sect. 4.1), they could affect calculated trends due to their interannual variability, especially if strong biomass burning events occur at the beginning or end of the considered time period. We use the presented annual growth rates to investigate this influence of biomass burning on our time series. Ethane growth rates at Zugspitze are mostly positive in the 2007-2014 period and mostly negative in the 1999-2006 period with exception of the years 2002 and 2003. This strong ethane growth could be related to boreal biomass burning events in this time period (Simmonds et al., 2005; Simpson et al., 2006). A similar pattern is seen in 2012 and 2013, which is possibly also caused by a biomass burning emission peak in boreal Asia as reported in the Global Fire Emission Database GFED4s (Giglio et al., 2013). At Lauder, relatively high ethane column-averaged mole fractions and associated higher growth rates are observed in October and November 2010 (see Figs. 1 and A1). Similar peaks in late 2010 are present in the time series of total columns of biomass burning tracers $\mathrm{HCN}$ and $\mathrm{CO}$ at Lauder. This suggests that a biomass burning event caused these high ethane observations. Biomass burning emission data from the Global Fire Emission Database reveal no strong fire activity in 2010 within the region of Australia and New Zealand. In contrast, an exceptionally large monthly burned area is recorded in August and September 2010 in Southern Hemisphere South America probably connected to a strong La Niña event. Related biomass burning emissions can be convected to the upper troposphere and transported by westerly winds to New Zealand within 1-2 weeks (Rinsland et al., 1998, 2001; Staudt et al., 2002). The dominance of such transport patterns during the respective measurement period in 2010 is confirmed using backward trajectories (Stein et al., 2015; available at http://ready.arl.noaa.gov/HYSPLIT_traj. php). In summary, strong biomass burning events introduce interannual variability in the presented ethane and methane time series but should not have major effects on our trend estimates as they primarily occur within the considered time periods and not at their beginning or end.

\section{Appendix B: Atmospheric two-box model}

In Sect. 4.2 we simulate hemispheric annual mean columnaveraged mole fractions of methane and ethane using an atmospheric two-box model. Hemispheric growth rates are determined by hemispheric emissions, chemical loss due to the reaction with $\mathrm{OH}$, and interhemispheric exchange, as expressed in the following equations:

$\frac{\mathrm{d} X_{\mathrm{N}}}{\mathrm{d} t}=E_{\mathrm{N}}-\frac{X_{\mathrm{N}}}{\lambda}-\frac{X_{\mathrm{N}}-X_{\mathrm{S}}}{\tau_{\mathrm{ex}}}$

and

$\frac{\mathrm{d} X_{\mathrm{S}}}{\mathrm{d} t}=E_{\mathrm{S}}-\frac{X_{\mathrm{S}}}{\lambda}+\frac{X_{\mathrm{N}}-X_{\mathrm{S}}}{\tau_{\mathrm{ex}}}$.

Here, $X_{\mathrm{N}}$ and $X_{\mathrm{S}}$ are mean column-averaged mole fractions in the Northern and Southern Hemisphere, $\lambda$ is the tracer atmospheric lifetime (assumed constant), and $\tau_{\text {ex }}$ is the interhemispheric exchange time. $E_{\mathrm{N}}$ and $E_{\mathrm{S}}$ are total hemispheric tracer emissions (in units of $\mathrm{ppb} \mathrm{yr}^{-1}$ ), which can be determined from global emissions $E_{\text {global }}$ (in $\mathrm{Tg} \mathrm{yr}^{-1}$ ) with the conversion factor $c\left(\mathrm{Tg} \mathrm{ppb}^{-1}\right)$ and the fraction $f_{\mathrm{N}}$ of global emissions in the northern hemisphere according to $E_{\mathrm{N}}=f_{\mathrm{N}} \times E_{\text {global }} \times 2 / c$ and $E_{\mathrm{S}}=\left(1-f_{\mathrm{N}}\right) \times E_{\text {global }} \times 2 / c$. The two-box model described in Equations (B1) and (B2) can be used to model the time series of methane (e.g., Kai et al., 2011) as well as ethane (e.g., Aydin et al., 2011). The two-box model parameters and their uncertainties as used in this study are summarized in Table B1 for methane and in Table B2 for ethane. Uncertainty ranges are given as stated in the reference cited or, if not included there, as a range of literature values.

The primary sink for both species is oxidation by $\mathrm{OH}$, which has not shown any large interannual variability since the late 1970s (IPCC, 2013, p. 167). Therefore, we apply a constant atmospheric lifetime of methane $(8.9 \pm 1.0$ years; Turner et al., 2015) and ethane (2.6 \pm 0.6 months; Xiao et al., 2008) in our two-box model. Assuming a constant lifetime implies that potential interannual variability of $\mathrm{OH}$ is projected to the modeled source term (see Bergamaschi et al., 2013; Dlugokencky et al., 1998). However, Kai et al. (2011) found no significant difference between two-box model simulations with constant and time-dependent methane lifetime including the feedback of $\mathrm{CH}_{4}$ on $\mathrm{OH}$ concentrations. 

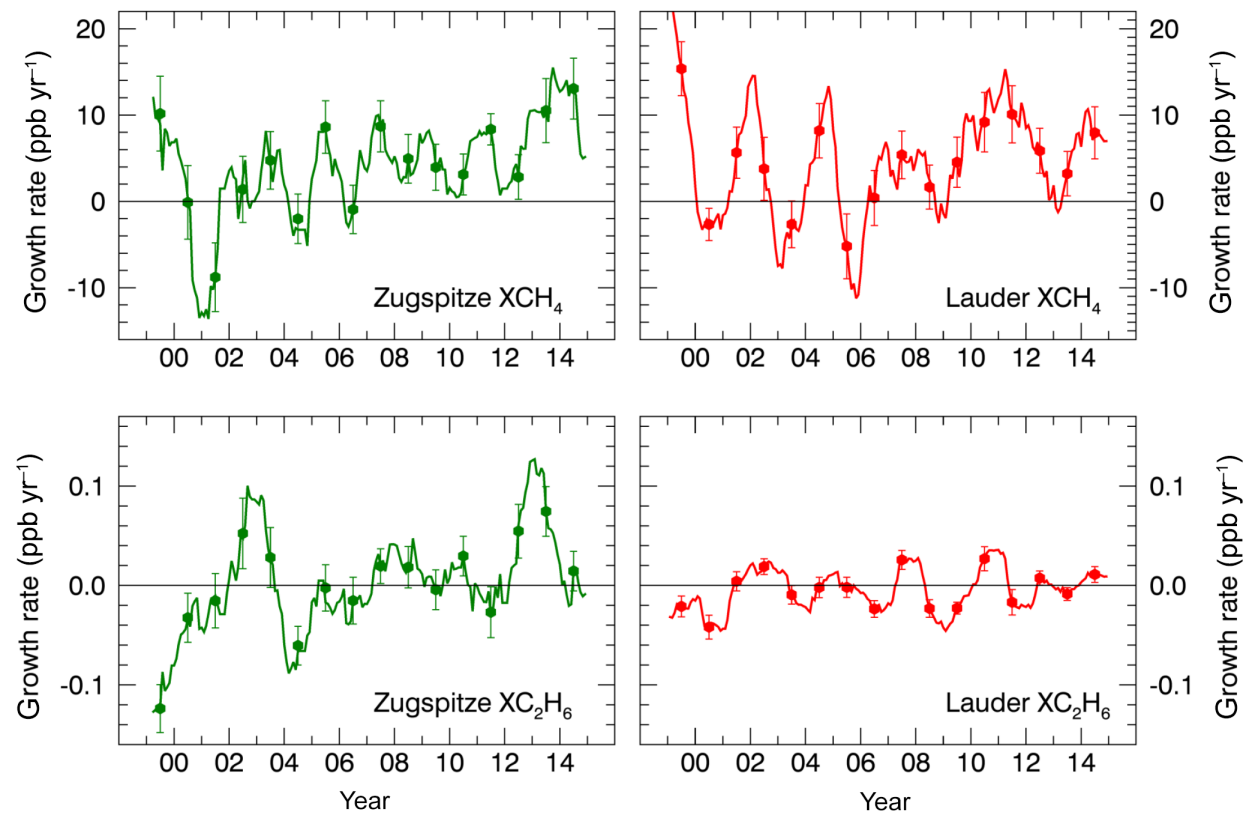

Figure A1. Annual growth rates of column-averaged methane and ethane at Zugspitze (left panels) and Lauder (right panels). Annual increases are calculated as the difference between two consecutive annual means (filled circles). Annual running mean growth rates are depicted as solid lines (see text for details).

Table B1. Uncertainty of methane two-box model parameters and implied trend uncertainty.

\begin{tabular}{llll}
\hline Model parameter & Reference & Parameter range & Trend (ppb yr $\left.{ }^{-1}\right)$ \\
\hline Lifetime (yr) & Turner et al. (2015) & $8.9[7.9,9.9]$ & $6.21[5.88,6.53]$ \\
Interhemispheric exchange (yr) & Patra et al. (2009) & $0.98[0.55,1.41]$ & $6.21[6.10,6.32]$ \\
Conversion (Tg ppb $\left.{ }^{-1}\right)^{*}$ & Patra et al. (2011) & $2.845[2.767,2.870]$ & $6.21[6.39,6.16]$ \\
NH emission fraction (\%) & Kai et al. (2011) & $0.70[0.65,0.75]$ & $6.21[6.14,6.28]$ \\
Global emissions (Tg yr $\left.{ }^{-1}\right):$ & & & \\
$1980 \mathrm{~s}$ & IPCC (2013, p. 507) & $541[500,592]$ & $6.21[7.51,4.60]$ \\
$1990 \mathrm{~s}$ & IPCC (2013, p. 507) & $554[529,596]$ & $6.21[7.87,3.42]$ \\
2000s & IPCC (2013, p. 507) & $553[526,569]$ & $6.21[3.55,7.79]$ \\
$1980-2010$ & IPCC (2013, p. 507) & all decades min or max & $6.21[6.51,3.38]$ \\
\hline
\end{tabular}

* Conversion of mole fractions ( $\mathrm{ppb} \mathrm{yr}^{-1}$ ) to emissions $\left(\mathrm{Tg} \mathrm{yr}^{-1}\right)$.

Initial global methane emissions are taken from top-down estimates of total methane emissions (IPCC, 2013, p. 507). In the case of ethane three source categories are distinguished: fossil fuel extraction (oil, gas, and coal), biomass burning, and biofuel use. Initial global ethane emissions are compiled from the following emission inventories: (i) biomass burning emissions from the Global Fire Emission Database GFED4s (van der Werf et al., 2010; Giglio et al., 2013) with emission factors from Akagi et al. (2011), (ii) biofuel use emissions from the linearly extrapolated activity data in Fernandes et al. (2007) with appropriate emission factors (Andreae and Merlet, 2001), and (iii) fossil-fuel-related emissions provided in Schwietzke et al. (2014). The latter includes annual emissions up to 2011 from the extraction of coal (EMR $=0.5 \%$ or MER $=100)$, oil $(E M R=21.3 \%$ or $\mathrm{MER}=2.5)$, and natural gas (mean ethane content of $7.3 \%$ at a global fugitive emission rate of 5\%). Initial emission estimates for 2012-2014 are obtained by extrapolation according to the annual percentage change in the global production of coal (OECD/IEA, 2015), oil, and gas (US Energy Information Administration, 2015).

Other ethane emissions from oceanic or biogenic sources are negligibly small (Rudolph, 1995; Xiao et al., 2008) and not considered in this work. Furthermore, we do not include a possible ethane source from geologic outgassing based on the following considerations: Simpson et al. (2012) state that a large geologic ethane source is unlikely, but more investigation would be required for confirmation. Recently, Nicewonger et al. (2016) report preindustrial geologic ethane emissions of $2.2-3.5 \mathrm{Tg} \mathrm{vr}^{-1}$, similar to a present-day esti- 
Table B2. Uncertainty of ethane two-box model parameters and implied trend uncertainty.

\begin{tabular}{|c|c|c|c|}
\hline Model Parameter & Reference & Parameter Range & Trend $\left(10^{-2} \mathrm{ppb} \mathrm{yr}^{-1}\right)$ \\
\hline Lifetime (month) & Xiao et al. (2008) & $2.6[2.0,3.2]$ & $2.27[1.79,2.72]$ \\
\hline Interhemispheric exchange (yr) & Patra et al. (2009) & $0.98[0.55,1.41]$ & $2.27[2.11,2.35]$ \\
\hline Conversion $\left(\mathrm{Tg} \mathrm{ppb}^{-1}\right)^{\mathrm{a}}$ & Rudolph (1995) & $18[10,26]$ & $2.27[4.08,1.57]$ \\
\hline \multicolumn{4}{|l|}{$\mathrm{NH}$ emission fraction $(\%)$ : } \\
\hline Biomass burning & GFED4s ${ }^{b}$ & $53[48,58]$ & $2.27[2.26,2.27]$ \\
\hline Biofuel use & Xiao et al. (2008) & $81[73,89]$ & $2.27[2.26,2.27]$ \\
\hline Coal & Schwietzke et al. (2014) & $90[81,99]$ & $2.27[2.26,2.27]$ \\
\hline Oil and gas & Schwietzke et al. (2014) & $95[86,100]$ & $2.27[2.11,2.35]$ \\
\hline \multicolumn{4}{|l|}{ Global emissions $\left(\mathrm{Tg} \mathrm{yr}^{-1}\right)$ : } \\
\hline Biomass burning & GFED $4 s^{b}$ & $\pm 65 \%$ & $2.27[2.19,2.34]$ \\
\hline Optimized annual methane and Biofuel use & Fernandes et al. (2007) & $\pm 75 \%$ & $2.27[2.22,2.31]$ \\
\hline Coal & Schwietzke et al. (2014) & $\pm 90 \%$ & $2.27[2.23,2.30]$ \\
\hline Oil & Schwietzke et al. (2014) & $\pm 40 \%$ & $2.27[2.19,2.35]$ \\
\hline Gas & Schwietzke et al. (2014) & $\pm 50 \%$ & $2.27[2.01,2.53]$ \\
\hline
\end{tabular}

${ }^{\mathrm{a}}$ Conversion of mole fractions ( $\mathrm{ppb} \mathrm{yr}^{-1}$ ) to emissions $\left(\mathrm{Tg} \mathrm{yr}^{-1}\right){ }^{\mathrm{b}}$ Global Fire Emission Database version 4 (van der Werf et al., 2010).

mate by Etiope and Ciccioli (2009). However, the temporal variability of geologic emissions is poorly known and assuming constant source strength may be reasonable (Nicewonger et al., 2016). Implementing a two-box model scenario with an additional constant geologic ethane source does not considerably change the derived optimized increase in oil and natural gas ethane emissions since 2007 (change

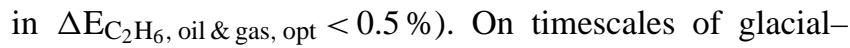
interglacial transitions fluctuations in geologic emissions are possible in response to variable crustal loading or continental shelf exposure (Nicewonger et al., 2016). Such long-term variations can be linearly approximated for the much shorter period considered here ( 7 years). Hence, in a second scenario we assume linearly increasing geologic emissions since 2007. If this linear increase is chosen strong enough to fully account for the observed positive ethane trend in 2007-2014, geologic emissions would have to increase by about $190 \%$. An increase of this strength does not seem to be reasonable and is not evident from the literature. Consequently, we do not consider geologic ethane emissions in our box model as done in several previous ethane studies (Pozzer et al., 2010; Aydin et al., 2011; Franco et al., 2015). 
Acknowledgements. We thank H. P. Schmid (IMK-IFU) for his continual interest in this work. We gratefully acknowledge Frank Hase (IMK-ASF) for his support in using PROFFIT. Our work has been performed as part of the ESA GHG-cci project. In addition we acknowledge funding by the EC within the INGOS project. We are grateful for support from the Deutsche Forschungsgemeinschaft and Open Access Publishing Fund of the Karlsruhe Institute of Technology. Measurements conducted at Lauder, New Zealand, are supported by NIWA as part of its government-funded core research, funded by New Zealand's Ministry of Business, Innovation \& Employment. Furthermore, we greatly appreciate the permission given by E. Mahieu to use Jungfraujoch NDACC data.

The article processing charges for this open-access

publication were covered by a Research

Centre of the Helmholtz Association.

Edited by: H. Maring

\section{References}

Akagi, S. K., Yokelson, R. J., Wiedinmyer, C., Alvarado, M. J., Reid, J. S., Karl, T., Crounse, J. D., and Wennberg, P. O.: Emission factors for open and domestic biomass burning for use in atmospheric models, Atmos. Chem. Phys., 11, 4039-4072, doi:10.5194/acp-11-4039-2011, 2011.

Andreae, M. O. and Merlet, P.: Emission of trace gases and aerosols from biomass burning, Global Biogeochem. Cy., 15, 955-966, 2001.

Angelbratt, J., Mellqvist, J., Simpson, D., Jonson, J. E., Blumenstock, T., Borsdorff, T., Duchatelet, P., Forster, F., Hase, F., Mahieu, E., De Mazière, M., Notholt, J., Petersen, A. K., Raffalski, U., Servais, C., Sussmann, R., Warneke, T., and Vigouroux, C.: Carbon monoxide $(\mathrm{CO})$ and ethane $\left(\mathrm{C}_{2} \mathrm{H}_{6}\right)$ trends from ground-based solar FTIR measurements at six European stations, comparison and sensitivity analysis with the EMEP model, Atmos. Chem. Phys., 11, 9253-9269, doi:10.5194/acp-11-92532011, 2011.

Aydin, M., Verhulst, K. R., Saltzman, E. S., Battle, M. O., Montzka, S. A., Blake, D. R., Tang, Q., and Prather, M. J.: Recent decreases in fossil-fuel emissions of ethane and methane derived from firn air, Nature, 476, 198-201, doi:10.1038/nature10352, 2011.

Bergamaschi, P., Houweling, S., Segers, A., Krol, M., Frankenberg, C., Scheepmaker, R. A., Dlugokencky, E., Wofsy, S. C., Kort, E. A., Sweeney, C., Schuck, T., Brenninkmeijer, C., Chen, H., Beck, V., and Gerbig, C.: Atmospheric $\mathrm{CH}_{4}$ in the first decade of the 21st century: Inverse modeling analysis using SCIAMACHY satellite retrievals and NOAA surface measurements, J. Geophys. Res.-Atmos., 118, 7350-7369, doi:10.1002/jgrd.50480, 2013.

Borbon, A., Gilman, J., Kuster, W., Grand, N., Chevaillier, S., Colomb, A., Dolgorouky, C., Gros, V., Lopez, M., Sarda-Esteve, R., Holloway, J., Stutz, J., Petetin, H., McKeen, S., Beekmann, M., Warneke, C., Parrish, D. D., and de Gouw, J. A.: Emission ratios of anthropogenic volatile organic compounds in northern midlatitude megacities: Observations versus emission inventories in Los Angeles and Paris, J. Geophys. Res.-Atmos., 118, 2041-2057, doi:10.1002/jgrd.50059, 2013.
Bousquet, P., Ringeval, B., Pison, I., Dlugokencky, E. J., Brunke, E.G., Carouge, C., Chevallier, F., Fortems-Cheiney, A., Frankenberg, C., Hauglustaine, D. A., Krummel, P. B., Langenfelds, R. L., Ramonet, M., Schmidt, M., Steele, L. P., Szopa, S., Yver, C., Viovy, N., and Ciais, P.: Source attribution of the changes in atmospheric methane for 2006-2008, Atmos. Chem. Phys., 11, 3689-3700, doi:10.5194/acp-11-3689-2011, 2011.

Brandt, A. R., Heath, G. A., Kort, E. A., O'Sullivan, F., Pétron, G., Jordaan, S., Tans, P., Wilcox, J., Gopstein, A. M., Arent, D., Wofsy, S., Brown, N. J., Bradley, R., Stucky, G. D., Eardley, D., and Harriss, R.: Methane Leaks from North American Natural Gas Systems, Science, 343, 733-735, doi:10.1126/science.1247045, 2014.

Bruhwiler, L., Dlugokencky, E., Masarie, K., Ishizawa, M., Andrews, A., Miller, J., Sweeney, C., Tans, P., and Worthy, D.: CarbonTracker- $\mathrm{CH}_{4}$ : an assimilation system for estimating emissions of atmospheric methane, Atmos. Chem. Phys., 14, 82698293, doi:10.5194/acp-14-8269-2014, 2014.

Dils, B., Cui, J., Henne, S., Mahieu, E., Steinbacher, M., and De Mazière, M.: 1997-2007 CO trend at the high Alpine site Jungfraujoch: a comparison between NDIR surface in situ and FTIR remote sensing observations, Atmos. Chem. Phys., 11, 6735-6748, doi:10.5194/acp-11-6735-2011, 2011.

Dlugokencky, E., Masarie, K., Lang, P., and Tans, P.: Continuing decline in the growth rate of the atmospheric methane burden, Nature, 393, 447-450, 1998.

Dlugokencky, E. J., Bruhwiler, L., White, J. W. C., Emmons, L. K., Novelli, P. C., Montzka, S. A., Masarie, K. A., Lang, P. M., Crotwell, A. M., Miller, J. B., and Gatti, L. V.: Observational constraints on recent increases in the atmospheric $\mathrm{CH}_{4}$ burden, Geophys. Res. Lett., 36, L18803, doi:10.1029/2009GL039780, 2009.

Dlugokencky, E. J., Nisbet, E. G., Fisher, R., and Lowry, D.: Global atmospheric methane: budget, changes and dangers, Philos. T. Roy. Soc. A, 369, 2058-2072, doi:10.1098/rsta.2010.0341, 2011.

Dlugokencky, E. J., Crotwell, A. M., Crotwell, M., Lang, P. M., Masarie, K. A., Michel, S., and Bruhwiler, L.: What have we learned from three decades of atmospheric $\mathrm{CH}_{4}$ measurements?, International Conference on non- $\mathrm{CO}_{2}$ Greenhouse Gases, InGOS, Utrecht, The Netherlands, 21-24 September 2015a.

Dlugokencky, E. J., Lang, P. M., Crotwell, A. M., Masarie, K. A., and Crotwell, M. J.: Atmospheric Methane Dry Air Mole Fractions from the NOAA ESRL Carbon Cycle Cooperative Global Air Sampling Network, available at: ftp://aftp.cmdl.noaa. gov/data/trace_gases/ch4/flask/surface (last access: 16 February 2016), 2015 b.

Etiope, G. and Ciccioli, P.: Earth's degassing: a missing ethane and propane source, Science, 323, 478-478, doi:10.1126/science.1165904, 2009.

Fernandes, S. D., Trautmann, N. M., Streets, D. G., Roden, C. A., and Bond, T. C.: Global biofuel use, 1850-2000, Global Biogeochem. Cy., 21, GB2019, doi:10.1029/2006gb002836, 2007.

Field, R., Soltis, J., and Murphy, S.: Air quality concerns of unconventional oil and natural gas production, Environ. Sci. Process. Impacts, 16, 954-969, doi:10.1039/c4em00081a, 2014.

Franco, B., Bader, W., Toon, G., Bray, C., Perrin, A., Fischer, E., Sudo, K., Boone, C., Bovy, B., Lejeune, B., Servais, C., and Mahieu, E.: Retrieval of ethane from ground-based FTIR solar spectra using improved spectroscopy: Recent burden in- 
crease above Jungfraujoch, J. Quant. Spectrosc. Ra., 160, 36-49, doi:10.1016/j.jqsrt.2015.03.017, 2015.

Frankenberg, C., Aben, I., Bergamaschi, P., Dlugokencky, E. J., van Hees, R., Houweling, S., van der Meer, P., Snel, R., and Tol, P.: Global column-averaged methane mixing ratios from 2003 to 2009 as derived from SCIAMACHY: Trends and variability, J. Geophys. Res., 116, D04302, doi:10.1029/2010JD014849, 2011.

Garcia, R. R., Marsh, D. R., Kinnison, D. E., Boville, B. A., and Sassi, F.: Simulation of secular trends in the middle atmosphere, 1950-2003, J. Geophys. Res., 112, D09301, doi:10.1029/2006JD007485, 2007.

Gardiner, T., Forbes, A., de Mazière, M., Vigouroux, C., Mahieu, E., Demoulin, P., Velazco, V., Notholt, J., Blumenstock, T., Hase, F., Kramer, I., Sussmann, R., Stremme, W., Mellqvist, J., Strandberg, A., Ellingsen, K., and Gauss, M.: Trend analysis of greenhouse gases over Europe measured by a network of ground-based remote FTIR instruments, Atmos. Chem. Phys., 8, 6719-6727, doi:10.5194/acp-8-6719-2008, 2008.

Giglio, L., Randerson, J. T., and van der Werf, G. R.: Analysis of daily, monthly, and annual burned area using the fourthgeneration global fire emissions database (GFED4), J. Geophys. Res.-Biogeo., 118, 317-328, doi:10.1002/jgrg.20042, 2013.

Hase, F., Hannigan, J., Coffey, M., Goldman, A., Höpfner, M., Jones, N., Rinsland, C., and Wood, S.: Intercomparison of retrieval codes used for the analysis of high-resolution, groundbased FTIR measurements, J. Quant. Spectrosc. Ra., 87, 25-52, doi:10.1016/j.jqsrt.2003.12.008, 2004.

Heimann, M.: Atmospheric science: Enigma of the recent methane budget, Nature, 476, 157-158, doi:10.1038/476157a, 2011.

Helmig, D., Petrenko, V., Martinerie, P., Witrant, E., Röckmann, T., Zuiderweg, A., Holzinger, R., Hueber, J., Thompson, C., White, J. W. C., Sturges, W., Baker, A., Blunier, T., Etheridge, D., Rubino, M., and Tans, P.: Reconstruction of Northern Hemisphere 1950-2010 atmospheric non-methane hydrocarbons, Atmos. Chem. Phys., 14, 1463-1483, doi:10.5194/acp-14-14632014, 2014.

Howarth, R. W.: A bridge to nowhere: methane emissions and the greenhouse gas footprint of natural gas, Energy Sci. Eng., 2, 4760, doi:10.1002/ese 3.35, 2014.

IPCC: Climate Change 2013: The Physical Science Basis. Contribution of Working Group I to the Fifth Assessment Report of the Intergovernmental Panel on Climate Change, edited by: Stocker, T. F., Qin, D., Plattner, G.-K., Tignor, M., Allen, S. K., Boschung, J., Nauels, A., Xia, Y., Bex, V., and Midgley, P. M., Cambridge University Press, Cambridge, United Kingdom and New York, NY, USA, 2013.

IRWG (Infrared Working Group): Uniform Retrieval Parameter Summary, available at: http://www.acom.ucar.edu/irwg/IRWG_ Uniform_RP_Summary-3.pdf (last access: 18 December 2015), 2014

Jackson, R. B., Down, A., Phillips, N. G., Ackley, R. C., Cook, C. W., Plata, D. L., and Zhao, K.: Natural gas pipeline leaks across Washington, DC, Environ. Sci. Technol., 48, 2051-2058, doi:10.1021/es404474x, 2014.

Kai, F. M., Tyler, S. C., Randerson, J. T., and Blake, D. R.: Reduced methane growth rate explained by decreased Northern Hemisphere microbial sources, Nature, 476, 194-197, doi:10.1038/nature10259, 2011.
Kang, M., Kanno, C. M., Reid, M. C., Zhang, X., Mauzerall, D. L., Celia, M. A., Chen, Y., and Onstott, T. C.: Direct measurements of methane emissions from abandoned oil and gas wells in Pennsylvania, P. Natl. Acad. Sci. USA, 111, 18173-18177, doi:10.1073/pnas.1408315111, 2014.

Karion, A., Sweeney, C., Pétron, G., Frost, G., Hardesty, R. M., Kofler, J., Miller, B. R., Newberger, T., Wolter, S., Banta, R., Brewer, A., Dlugokencky, E., Lang, P., Montzka, S. A., Schnell, R., Tans, P., Trainer, M., Zamora, R., and Conley, S.: Methane emissions estimate from airborne measurements over a western United States natural gas field, Geophys. Res. Lett., 40, 4393 4397, doi:10.1002/grl.50811, 2013.

Kirschke, S., Bousquet, P., Ciais, P., Saunois, M., Canadell, J. G., Dlugokencky, E. J., Bergamaschi, P., Bergmann, D., Blake, D. R., Bruhwiler, L., Cameron-Smith, P., Castaldi, S., Chevallier, F., Feng, L., Fraser, A., Heimann, M., Hodson, E. L., Houweling, S., Josse, B., Fraser, P. J., Krummel, P. B., Lamarque, J.F., Langenfelds, R. L., Le Quéré, C., Naik, V., O’Doherty, S., Palmer, P. I., Pison, I., Plummer, D., Poulter, B., Prinn, R. G., Rigby, M., Ringeval, B., Santini, M., Schmidt, M., Shindell, D. T., Simpson, I. J., Spahni, R., Steele, L. P., Strode, S. A., Sudo, K., Szopa, S., van der Werf, G. R., Voulgarakis, A., van Weele, M., Weiss, R. F., Williams, J. E., and Zeng, G.: Three decades of global methane sources and sinks, Nat. Geosci., 6, 813-823, doi:10.1038/ngeo1955, 2013.

Kort, E. A., Frankenberg, C., Costigan, K. R., Lindenmaier, R., Dubey, M. K., and Wunch, D.: Four corners: The largest US methane anomaly viewed from space, Geophys. Res. Lett., 41, 6898-6903, doi:10.1002/2014gl061503, 2014.

Levin, I., Veidt, C., Vaughn, B. H., Brailsford, G., Bromley, T., Heinz, R., Lowe, D., Miller, J. B., Poß, C., and White, J. W. C.: No inter-hemispheric $\delta^{13} \mathrm{CH}_{4}$ trend observed, Nature, 486, E3-E4, doi:10.1038/nature11175, 2012.

Miller, S. M., Wofsy, S. C., Michalak, A. M., Kort, E. A., Andrews, A. E., Biraud, S. C., Dlugokencky, E. J., Eluszkiewicz, J., Fischer, M. L., Janssens-Maenhout, G., Miller, B. R., Miller, J. B., Montzka, S. A., Nehrkorn, T., and Sweeney, C.: Anthropogenic emissions of methane in the United States, P. Natl. Acad. Sci. USA, 110, 20018-20022, doi:10.1073/pnas.1314392110, 2013.

Montzka, S. A., Krol, M., Dlugokencky, E., Hall, B., Jöckel, P., and Lelieveld, J.: Small interannual variability of global atmospheric hydroxyl, Science, 331, 67-69, doi:10.1126/science.1197640, 2011.

Moore, C. W., Zielinska, B., Pétron, G., and Jackson, R. B.: Air Impacts of Increased Natural Gas Acquisition, Processing, and Use: A Critical Review, Environ. Sci. Technol., 48, 8349-8359, doi:10.1021/es4053472, 2014

Nicewonger, M. R., Verhulst, K. R., Aydin, M., and Saltzman, E. S.: Preindustrial atmospheric ethane levels inferred from polar ice cores: A constraint on the geologic sources of atmospheric ethane and methane, Geophys. Res. Lett., 43, 214-221, doi:10.1002/2015GL066854, 2016.

Nisbet, E. and Weiss, R.: Top-Down Versus Bottom-Up, Science, 328, 1241-1243, doi:10.1126/science.1189936, 2010.

Nisbet, E. G., Dlugokencky, E. J., and Bousquet, P.: Methane on the Rise-Again, Science, 343, 493-495, doi:10.1126/science.1247828, 2014. 
Nisbet, E. G., Lowry, D., Zazzeri, G., Fisher, R., France, J., Brownlow, R., and Lanoisellé, M.: The use of C-isotopes in understanding the growth in atmospheric methane 2007-14, International Conference on non- $\mathrm{CO}_{2}$ Greenhouse Gases, InGOS, Utrecht, The Netherlands, 21-24 September 2015.

OECD/IEA: Excerpt from Coal Information (2015 edition), IEA Publishing, available at: http://www.iea.org/statistics/topics/coal, last access: 18 December 2015.

Ostler, A., Sussmann, R., Rettinger, M., Deutscher, N. M., Dohe, S., Hase, F., Jones, N., Palm, M., and Sinnhuber, B.-M.: Multistation intercomparison of column-averaged methane from NDACC and TCCON: impact of dynamical variability, Atmos. Meas. Tech., 7, 4081-4101, doi:10.5194/amt-7-4081-2014, 2014.

Parrish, D., Stohl, A., Forster, C., Atlas, E., Blake, D., Goldan, P., Kuster, W., and De Gouw, J.: Effects of mixing on evolution of hydrocarbon ratios in the troposphere, J. Geophys. Res., 112, D10S34, doi:10.1029/2006JD007583, 2007.

Patra, P. K., Takigawa, M., Dutton, G. S., Uhse, K., Ishijima, K., Lintner, B. R., Miyazaki, K., and Elkins, J. W.: Transport mechanisms for synoptic, seasonal and interannual $\mathrm{SF}_{6}$ variations and "age" of air in troposphere, Atmos. Chem. Phys., 9, 1209-1225, doi:10.5194/acp-9-1209-2009, 2009.

Patra, P. K., Houweling, S., Krol, M., Bousquet, P., Belikov, D., Bergmann, D., Bian, H., Cameron-Smith, P., Chipperfield, M. P., Corbin, K., Fortems-Cheiney, A., Fraser, A., Gloor, E., Hess, P., Ito, A., Kawa, S. R., Law, R. M., Loh, Z., Maksyutov, S., Meng, L., Palmer, P. I., Prinn, R. G., Rigby, M., Saito, R., and Wilson, C.: TransCom model simulations of $\mathrm{CH}_{4}$ and related species: linking transport, surface flux and chemical loss with $\mathrm{CH}_{4}$ variability in the troposphere and lower stratosphere, Atmos. Chem. Phys., 11, 12813-12837, doi:10.5194/acp-11-12813-2011, 2011.

Pétron, G., Karion, A., Sweeney, C., Miller, B. R., Montzka, S. A., Frost, G. J., Trainer, M., Tans, P., Andrews, A., Kofler, J., Helmig, D., Guenther, D., Dlugokencky, E., Lang, P., Newberger, T., Wolter, S., Hall, B., Novelli, P., Brewer, A., Conley, S., Hardesty, M., Banta, R., White, A., Noone, D., Wolfe, D., and Schnell, R.: A new look at methane and nonmethane hydrocarbon emissions from oil and natural gas operations in the Colorado Denver-Julesburg Basin, J. Geophys. Res.-Atmos., 119, 6836-6852, doi:10.1002/2013JD021272, 2014.

Pison, I., Ringeval, B., Bousquet, P., Prigent, C., and Papa, F.: Stable atmospheric methane in the 2000s: key-role of emissions from natural wetlands, Atmos. Chem. Phys., 13, 11609-11623, doi:10.5194/acp-13-11609-2013, 2013.

Pozzer, A., Pollmann, J., Taraborrelli, D., Jöckel, P., Helmig, D., Tans, P., Hueber, J., and Lelieveld, J.: Observed and simulated global distribution and budget of atmospheric $\mathrm{C}_{2}-\mathrm{C}_{5}$ alkanes, Atmos. Chem. Phys., 10, 4403-4422, doi:10.5194/acp-10-44032010, 2010.

Prather, M. J., Holmes, C. D., and Hsu, J.: Reactive greenhouse gas scenarios: Systematic exploration of uncertainties and the role of atmospheric chemistry, Geophys. Res. Lett., 39, L09803, doi:10.1029/2012GL051440, 2012.

Reichert, A., Hausmann, P., and Sussmann, R.: Pointing errors in solar absorption spectrometry - correction scheme and its validation, Atmos. Meas. Tech., 8, 3715-3728, doi:10.5194/amt-83715-2015, 2015.
Rigby, M., Prinn, R. G., Fraser, P. J., Simmonds, P. G., Langenfelds, R. L., Huang, J., Cunnold, D. M., Steele, L. P., Krummel, P. B., Weiss, R. F., O'Doherty, S., Salameh, P. K., Wang, H. J., Harth, C. M., Mühle, J., and Porter, L. W.: Renewed growth of atmospheric methane, Geophys. Res. Lett., 35, L22805, doi:10.1029/2008GL036037, 2008.

Rinsland, C. P., Jones, N. B., Connor, B. J., Logan, J. A., Pougatchev, N. S., Goldman, A., Murcray, F. J., Stephen, T. M., Pine, A. S., Zander, R., Mahieu, E., and Demoulin, P.: Northern and southern hemisphere ground-based infrared spectroscopic measurements of tropospheric carbon monoxide and ethane, J. Geophys. Res., 103, 28197-28217, 1998.

Rinsland, C. P., Meier, A., Griffith, D. W., and Chiou, L. S.: Groundbased measurements of tropospheric $\mathrm{CO}, \mathrm{C}_{2} \mathrm{H}_{6}$, and $\mathrm{HCN}$ from Australia at $34^{\circ} \mathrm{S}$ latitude during 1997-1998, J. Geophys. Res., 106, 20913-20924, 2001.

Rothman, L. S., Barbe, A., Benner, D. C., Brown, L. R., CamyPeyret, C., Carleer, M. R., Chance, K., Clerbaux, C., Dana, V., Devi, V. M., Fayt, A., Flaud, J.-M., Gamache, R. R., Goldman, A., Jacquemart, D., Jucks, K. W., Lafferty, W. J., Mandin, J.-Y., Massie, S. T., Nemtchinov, V., Newnham, D. A., Perrin, A., Rinsland, C. P., Schroeder, J., Smith, K. M., Smith, M. A. H., Tang, K., Toth, R. A., Vander Auwera, J., Varanasi, P., and Yoshino, K.: The HITRAN molecular spectroscopic database: edition of 2000 including updates through 2001, J. Quant. Spectrosc. Ra., 82, 5-44, doi:10.1016/s0022-4073(03)00146-8, 2003.

Rudolph, J.: The tropospheric distribution and budget of ethane, J. Geophys. Res., 100, 11369-11381, 1995.

Saito, R., Patra, P. K., Deutscher, N., Wunch, D., Ishijima, K., Sherlock, V., Blumenstock, T., Dohe, S., Griffith, D., Hase, F., Heikkinen, P., Kyrö, E., Macatangay, R., Mendonca, J., Messerschmidt, J., Morino, I., Notholt, J., Rettinger, M., Strong, K., Sussmann, R., and Warneke, T.: Technical Note: Latitude-time variations of atmospheric column-average dry air mole fractions of $\mathrm{CO}_{2}, \mathrm{CH}_{4}$ and $\mathrm{N}_{2} \mathrm{O}$, Atmos. Chem. Phys., 12, 7767-7777, doi:10.5194/acp12-7767-2012, 2012.

Sander, S. P., Abbatt, J., Barker, J. R., Burkholder, J. B., Friedl, R. R., Golden, D. M., Huie, R. E., Kolb, C. E., Kurylo, M. J., Moortgat, G. K., Orkin, V. L., and Wine, P. H.: Chemical Kinetics and Photochemical Data for Use in Atmospheric Studies, Evaluation No. 17, JPL Publication 10-6, Jet Propulsion Laboratory, Pasadena, USA, available at: http://jpldataeval.jpl.nasa.gov (last access: 18 December 2015), 2011.

Schneising, O., Burrows, J. P., Dickerson, R. R., Buchwitz, M., Reuter, M., and Bovensmann, H.: Remote sensing of fugitive methane emissions from oil and gas production in North American tight geologic formations, Earth's Future, 2, 548-558, doi:10.1002/2014EF000265, 2014.

Schoell, M.: The hydrogen and carbon isotopic composition of methane from natural gases of various origins, Geochim. Cosmochim. Acta, 44, 649-661, 1980.

Schwietzke, S., Griffin, W. M., Matthews, H. S., and Bruhwiler, L. M. P.: Global Bottom-Up Fossil Fuel Fugitive Methane and Ethane Emissions Inventory for Atmospheric Modeling, ACS Sustain. Chem. Eng., 2, 1992-2001, doi:10.1021/sc500163h, 2014. 
Simmonds, P. G., Manning, A. J., Derwent, R. G., Ciais, P., Ramonet, M., Kazan, V., and Ryall, D.: A burning question. Can recent growth rate anomalies in the greenhouse gases be attributed to large-scale biomass burning events?, Atmos. Environ., 39, 2513-2517, doi:10.1016/j.atmosenv.2005.02.018, 2005.

Simpson, I. J., Chen, T.-Y., Blake, D. R., and Rowland, F. S.: Implications of the recent fluctuations in the growth rate of tropospheric methane, Geophys. Res. Lett., 29, 117-1-117-4, doi:10.1029/2001g1014521, 2002.

Simpson, I. J., Rowland, F. S., Meinardi, S., and Blake, D. R.: Influence of biomass burning during recent fluctuations in the slow growth of global tropospheric methane, Geophys. Res. Lett., 33, L22808, doi:10.1029/2006GL027330, 2006.

Simpson, I. J., Sulbaek Andersen, M. P., Meinardi, S., Bruhwiler, L., Blake, N. J., Helmig, D., Rowland, F. S., and Blake, D. R.: Long-term decline of global atmospheric ethane concentrations and implications for methane, Nature, 488, 490-494, doi:10.1038/nature11342, 2012.

Staudt, A. C., Jacob, D. J., Logan, J. A., Bachiochi, D., Krishnamurti, T. N., and Poisson, N.: Global Chemical Model Analysis of Biomass Burning and Lightning Influences over the South Pacific in Austral Spring, J. Geophys. Res., 107, ACH 11-1-ACH 11-17, doi:10.1029/2000JD000296, 2002.

Stein, A. F., Draxler, R. R., Rolph, G. D., Stunder, B. J. B., Cohen, M. D., and Ngan, F.: NOAA's HYSPLIT atmospheric transport and dispersion modeling system, B. Am. Meteorol. Soc., 96, 2059-2077, doi:10.1175/BAMS-D-14-00110.1, 2015.

Stohl, A., Eckhardt, S., Forster, C., James, P., and Spichtinger, N.: On the pathways and timescales of intercontinental air pollution transport, J. Geophys. Res., 107, 4684, doi:10.1029/2001JD001396, 2002.

Sussmann, R. and Schäfer, K.: Infrared spectroscopy of tropospheric trace gases: combined analysis of horizontal and vertical column abundances, Appl. Opt., 36, 735-741, 1997.

Sussmann, R., Forster, F., Rettinger, M., and Jones, N.: Strategy for high-accuracy-and-precision retrieval of atmospheric methane from the mid-infrared FTIR network, Atmos. Meas. Tech., 4, 1943-1964, doi:10.5194/amt-4-1943-2011, 2011.

Sussmann, R., Forster, F., Rettinger, M., and Bousquet, P.: Renewed methane increase for five years (2007-2011) observed by solar FTIR spectrometry, Atmos. Chem. Phys., 12, 4885-4891, doi:10.5194/acp-12-4885-2012, 2012.

Sussmann, R., Ostler, A., Forster, F., Rettinger, M., Deutscher, N. M., Griffith, D. W. T., Hannigan, J. W., Jones, N., and Patra, P. K.: First intercalibration of column-averaged methane from the Total Carbon Column Observing Network and the Network for the Detection of Atmospheric Composition Change, Atmos. Meas. Tech., 6, 397-418, doi:10.5194/amt-6-397-2013, 2013.

Tans, P. P.: A note on isotopic ratios and the global atmospheric methane budget, Global Biogeochem. Cy., 11, 77-81, 1997.

Taylor, S. W., Sherwood Lollar, B., and Wassenaar, I.: Bacteriogenic Ethane in Near-Surface Aquifers: Implications for Leaking Hydrocarbon Well Bores, Environ. Sci. Technol., 34, 4727-4732, doi:10.1021/es001066x, 2000.

Toon, G.: Conversion of column abundances to dry-air mole fractions (and vice versa), available at: https://tccon-wiki.caltech. edu/@api/deki/files/375/=column_abundance.pdf (last access: 18 December 2015), 2008.
Turner, A. J., Jacob, D. J., Wecht, K. J., Maasakkers, J. D., Lundgren, E., Andrews, A. E., Biraud, S. C., Boesch, H., Bowman, K. W., Deutscher, N. M., Dubey, M. K., Griffith, D. W. T., Hase, F., Kuze, A., Notholt, J., Ohyama, H., Parker, R., Payne, V. H., Sussmann, R., Sweeney, C., Velazco, V. A., Warneke, T., Wennberg, P. O., and Wunch, D.: Estimating global and North American methane emissions with high spatial resolution using GOSAT satellite data, Atmos. Chem. Phys., 15, 7049-7069, doi:10.5194/acp-15-7049-2015, 2015.

US Energy Information Administration: Annual Energy Outlook 2014, DOE/EIA-0383(2014), Washington DC, 2014.

US Energy Information Administration: International Energy Statistics, available at: http://www.eia.gov/cfapps/ipdbproject, last access: 19 October 2015.

van der Werf, G. R., Randerson, J. T., Giglio, L., Collatz, G. J., Mu, M., Kasibhatla, P. S., Morton, D. C., DeFries, R. S., Jin, Y., and van Leeuwen, T. T.: Global fire emissions and the contribution of deforestation, savanna, forest, agricultural, and peat fires (19972009), Atmos. Chem. Phys., 10, 11707-11735, doi:10.5194/acp10-11707-2010, 2010.

Vigouroux, C., Stavrakou, T., Whaley, C., Dils, B., Duflot, V., Hermans, C., Kumps, N., Metzger, J.-M., Scolas, F., Vanhaelewyn, G., Müller, J.-F., Jones, D. B. A., Li, Q., and De Mazière, M.: FTIR time-series of biomass burning products $\left(\mathrm{HCN}, \mathrm{C}_{2} \mathrm{H}_{6}\right.$, $\mathrm{C}_{2} \mathrm{H}_{2}, \mathrm{CH}_{3} \mathrm{OH}$, and $\left.\mathrm{HCOOH}\right)$ at Reunion Island $\left(21^{\circ} \mathrm{S}, 55^{\circ}\right.$ E) and comparisons with model data, Atmos. Chem. Phys., 12, 10367-10385, doi:10.5194/acp-12-10367-2012, 2012.

Vinciguerra, T., Yao, S., Dadzie, J., Chittams, A., Deskins, T., Ehrman, S., and Dickerson, R. R.: Regional air quality impacts of hydraulic fracturing and shale natural gas activity: Evidence from ambient VOC observations, Atmos. Environ., 110, 144 150, doi:10.1016/j.atmosenv.2015.03.056, 2015.

Wang, Q., Chen, X., Jha, A. N., and Rogers, H.: Natural gas from shale formation - The evolution, evidences and challenges of shale gas revolution in United States, Renew. Sust. Energ Rev., 30, 1-28, doi:10.1016/j.rser.2013.08.065, 2014.

Wang, Y. and Zeng, T.: On tracer correlations in the troposphere: The case of ethane and propane, J. Geophys. Res., 109, D24306, doi:10.1029/2004JD005023, 2004.

Wennberg, P. O., Mui, W., Wunch, D., Kort, E. A., Blake, D. R., Atlas, E. L., Santoni, G. W., Wofsy, S. C., Diskin, G. S., Jeong, S., and Fischer, M. L.: On the Sources of Methane to the Los Angeles Atmosphere, Environ. Sci. Technol., 46, 9282-9289, doi:10.1021/es301138y, 2012.

Williams, J. and Koppmann, R.: Volatile Organic Compounds in the Atmosphere, in: Volatile Organic Compounds in the Atmosphere: An Overview, Blackwell Publishing, Oxford, UK, 1-32, 2007.

Xiao, Y., Logan, J. A., Jacob, D. J., Hudman, R. C., Yantosca, R., and Blake, D. R.: Global budget of ethane and regional constraints on U.S. sources, J. Geophys. Res., 113, D21306, doi:10.1029/2007jd009415, 2008.

Yacovitch, T. I., Herndon, S. C., Roscioli, J. R., Floerchinger, C., McGovern, R. M., Agnese, M., Pétron, G., Kofler, J., Sweeney, C., Karion, A., Conley, S. A., Kort, E. A., Nähle, L., Fischer, M., Hildebrandt, L., Koeth, J., McManus, J. B., Nelson, D. D., Zahniser, M. S., and Kolb, C. E.: Demonstration of an Ethane Spectrometer for Methane Source Identification, Environ. Sci. Technol., 48, 8028-8034, doi:10.1021/es501475q, 2014. 
Yokelson, R. J., Andreae, M. O., and Akagi, S. K.: Pitfalls with the use of enhancement ratios or normalized excess mixing ratios measured in plumes to characterize pollution sources and aging, Atmos. Meas. Tech., 6, 2155-2158, doi:10.5194/amt-62155-2013, 2013.
Zeng, G., Wood, S. W., Morgenstern, O., Jones, N. B., Robinson, J., and Smale, D.: Trends and variations in $\mathrm{CO}, \mathrm{C}_{2} \mathrm{H}_{6}$, and $\mathrm{HCN}$ in the Southern Hemisphere point to the declining anthropogenic emissions of $\mathrm{CO}$ and $\mathrm{C}_{2} \mathrm{H}_{6}$, Atmos. Chem. Phys., 12, 7543 7555, doi:10.5194/acp-12-7543-2012, 2012. 